\title{
\#USGS
}

science for a changing world

Prepared in cooperation with the U.S. Army Corps of Engineers

Demographic Responses of Least Terns and Piping Plovers to the 2011 Missouri River Flood-A Large-Scale Case Study
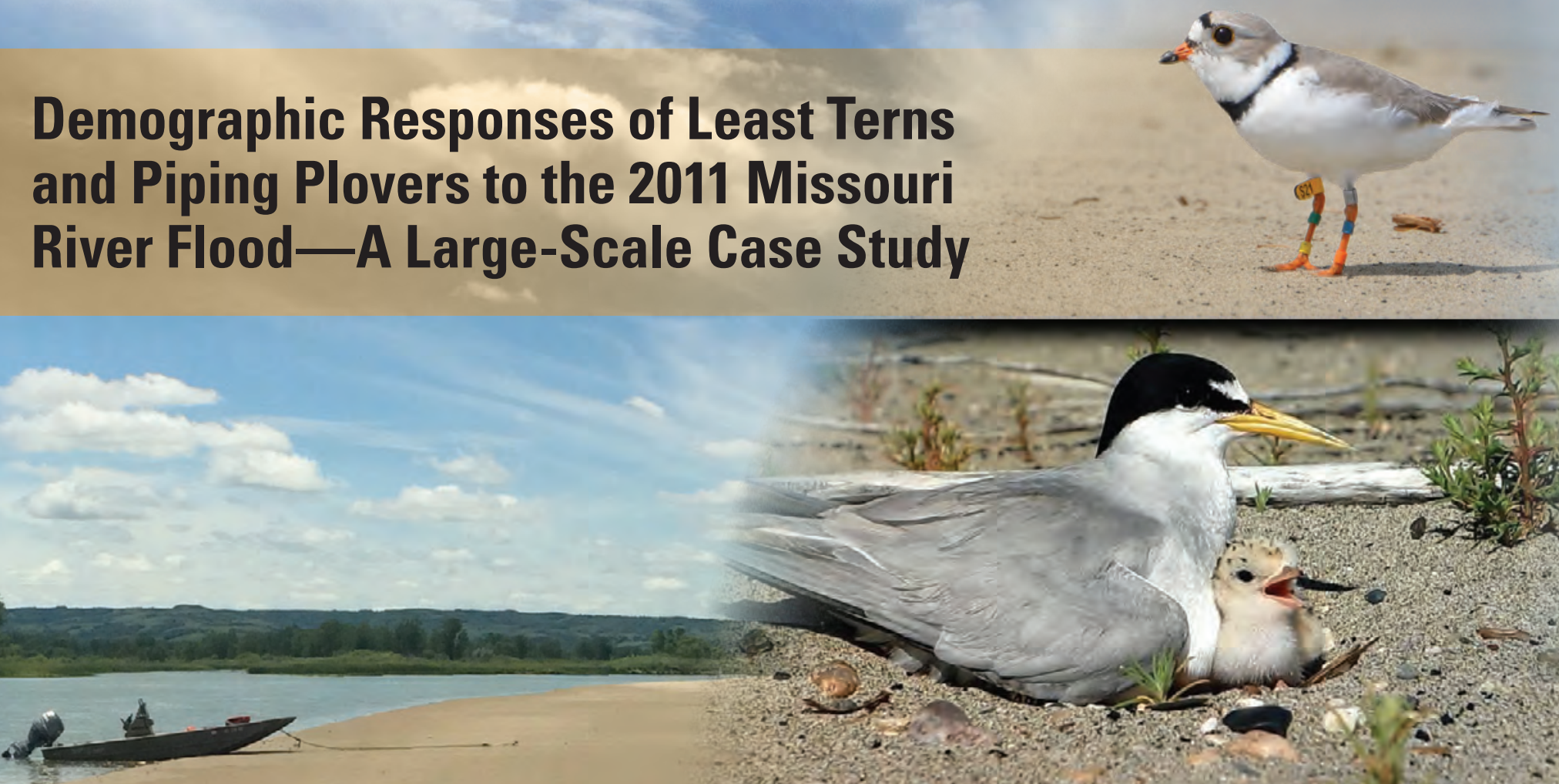

Open-File Report 2018-1176
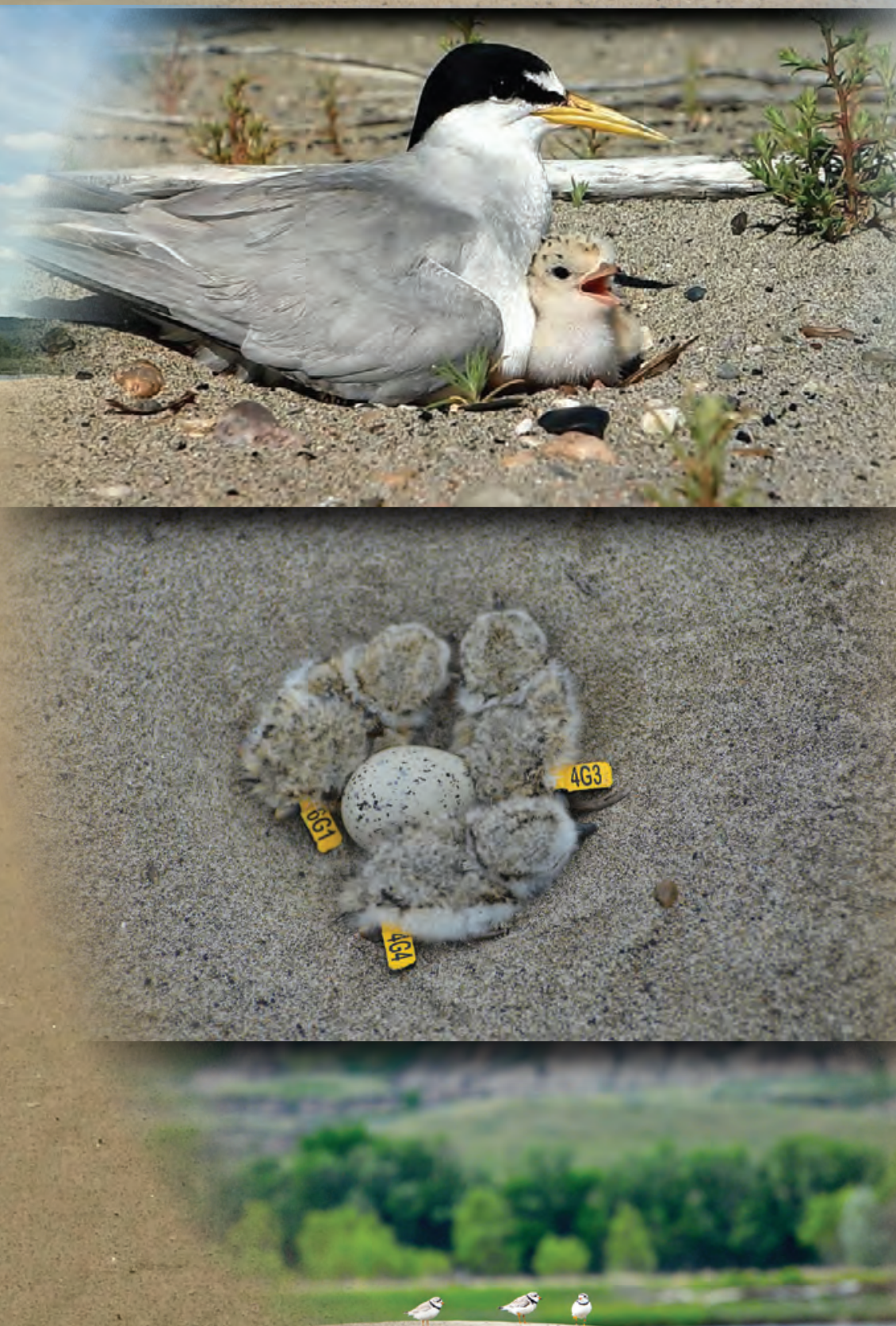

U.S. Department of the Interior

U.S. Geological Survey 
Cover. Background: Sandbar nesting habitat on the Garrison Reach of the Missouri River. Right-side photographs from top to bottom:

Banded adult piping plover.

Least tern adult and chick at a nest site.

Banded piping plover chicks in a nest bowl.

Banded piping plovers on a Missouri River sandbar.

Photographs by U.S. Geological Survey. 


\section{Demographic Responses of Least Terns and Piping Plovers to the 2011 Missouri River Flood-A Large-Scale Case Study}

By Michael J. Anteau, Mark H. Sherfy, Terry L. Shaffer, Rose J. Swift, Dustin L. Toy, and Colin M. Dovichin

Prepared in cooperation with the U.S. Army Corps of Engineers

Open-File Report 2018-1176 


\title{
U.S. Department of the Interior \\ DAVID BERNHARDT, Acting Secretary
}

\author{
U.S. Geological Survey \\ James F. Reilly II, Director
}

U.S. Geological Survey, Reston, Virginia: 2019

For more information on the USGS - the Federal source for science about the Earth, its natural and living resources, natural hazards, and the environment-visit https://www.usgs.gov or call 1-888-ASK-USGS.

For an overview of USGS information products, including maps, imagery, and publications,

visit https://store.usgs.gov.

Any use of trade, firm, or product names is for descriptive purposes only and does not imply endorsement by the U.S. Government.

Although this information product, for the most part, is in the public domain, it also may contain copyrighted materials as noted in the text. Permission to reproduce copyrighted items must be secured from the copyright owner.

Suggested citation:

Anteau, M.J., Sherfy, M.H., Shaffer, T.L., Swift, R.J., Toy, D.L., and Dovichin, C.M., 2019, Demographic responses of least terns and piping plovers to the 2011 Missouri River flood-A large-scale case study: U.S. Geological Survey Open-File Report 2018-1176, 33 p., https://doi.org/10.3133/ofr20181176.

ISSN 0196-1497 (print)

ISSN 2331-1258 (online)

ISBN 978-1-4113-4282-8 


\section{Acknowledgments}

This study was funded by the Integrated Science Program, Omaha District, U.S. Army Corps of Engineers, and the U.S. Geological Survey. We thank Casey Kruse, formerly of the Integrated Science Program, for posing the initial science questions and inviting Northern Prairie Wildlife Research Center to develop a least tern and piping plover research program on the Missouri River. We also thank Coral Huber, Greg Pavelka, Mike Delvaux, and Joe Bonneau for sustaining our long-term research collaboration with the Corps and for recognizing and supporting the scientific opportunity to evaluate flood responses of terns and plovers. We appreciate support and collaboration from other agencies and research entities, including the U.S. Fish and Wildlife Service, North Dakota Game and Fish Department, the Nature Conservancy, the Department of Biology at the University of North Dakota, and the Department of Fish and Wildlife Conservation at Virginia Tech.

The research team at Northern Prairie Wildlife Research Center contributed to this work in many ways that are impossible to recognize individually. Authorship of this report reflects those who contributed directly to producing the document, but does not identify all the individuals who participated in the larger effort to collect and analyze pre- and post-flood data. We especially appreciate the contributions of Erin Roche, Larry Strong, Jennifer Stucker, and Mark Wiltermuth in formulating the ideas and analyses presented here, and Max Post van der Burg in assisting with data analysis and generation of graphics. The hard work and dedication of over 100 seasonal field technicians who collected and archived the data is especially noteworthy. Jonathan Cohen and Conor McGowan provided detailed technical reviews of earlier drafts of this document. 



\section{Contents}

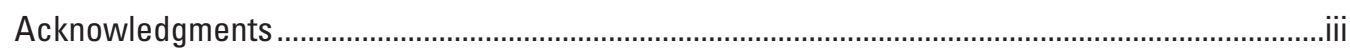

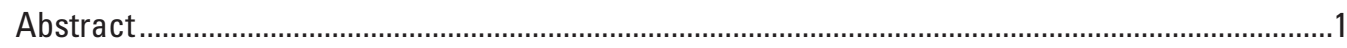

Introduction

Objectives

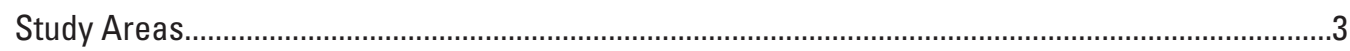

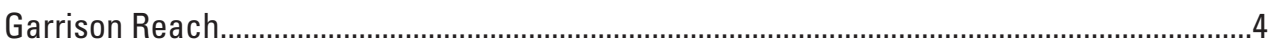

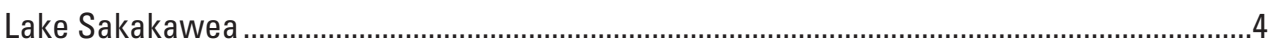

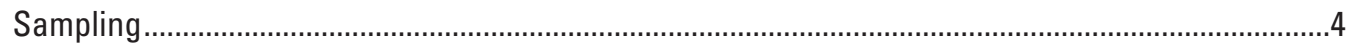

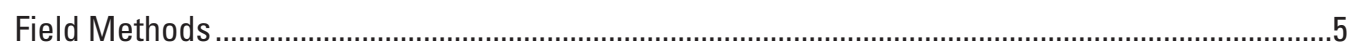

Nests

Chicks.

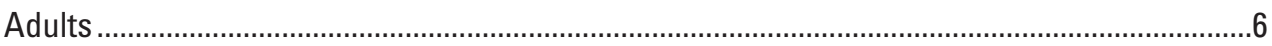

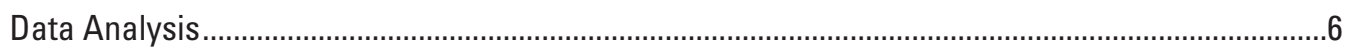

A Priori Predictions

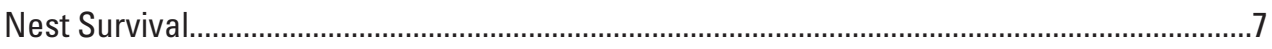

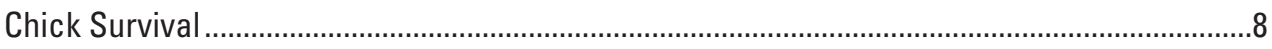

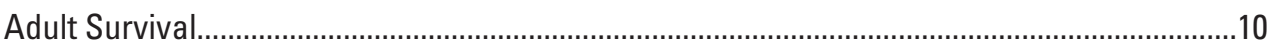

Breeding Population Size ........................................................................................... 10

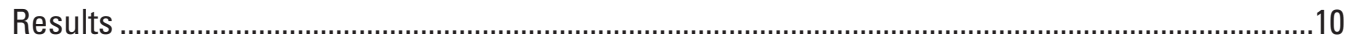

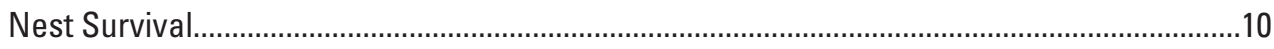

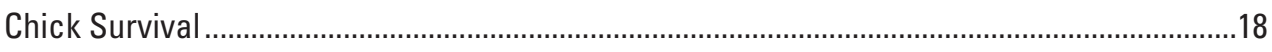

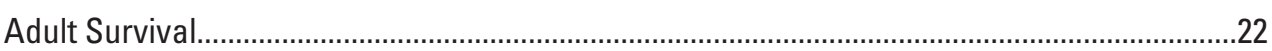

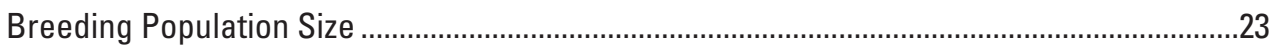

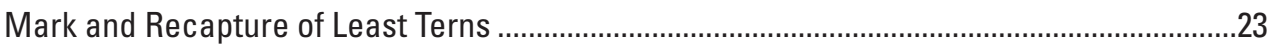

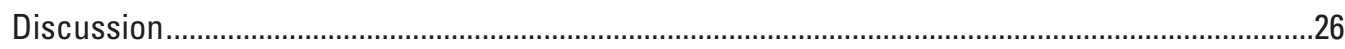

1. Estimate Survival to Hatch of Least Tern and Piping Plover Nests and Compare to Pre-Flood Estimates ...............................................................................26

2. Estimate Survival to Fledging Age of Least Tern and Piping Plover Chicks and Compare to Pre-Flood Estimates ......................................................................27

3. Estimate Annual Adult Survival of Piping Plovers and Compare to Pre-Flood Estimates .....................................................................................................28

4. Estimate Annual Breeding Population of Least Terns and Piping Plovers and Compare to Pre-Flood Estimates ...........................................................................29

5. Evaluate Feasibility of Mark-Resight Techniques to Estimate Site Fidelity and Annual Survival of Adult Least Terns ..................................................................31

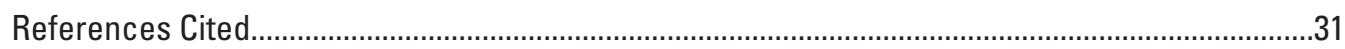




\section{Figures}

1. Map showing flood science study area during 2006-9 and 2012-14...

2. Graphs showing minimum breeding population (MINBPOP) regressions used to extrapolate MINBPOP/breeding population (BPOP) values for estimating BPOP for least terns and piping plovers nesting on Lake Sakakawea and the Garrison Reach during 2012-14.

3. Graph showing cumulative estimates of piping plover nest survival ( 35 days) along the Garrison Reach by year and for the pre-flood and post-flood periods

4. Graph showing cumulative estimates of piping plover nest survival (35 days) on Lake Sakakawea by year and for the pre-flood and post-flood periods.

5. Graph showing daily survival estimates for piping plover nests along the Garrison Reach by nest age and year

6. Graph showing cumulative estimates of piping plover nest survival (35 days)

along the Garrison Reach by nest initiation date and year....

7. Graph showing daily survival estimates for piping plover nests on Lake Sakakawea by nest age and year

8. Graph showing cumulative estimates of piping plover nest survival (35 days) on Lake Sakakawea by nest initiation date and year.

9. Graph showing cumulative estimates of least tern nest survival (21 days) along the Garrison Reach by year and for the pre-flood and post-flood periods 17

10. Graph showing daily survival estimates for least tern nests along the Garrison Reach by nest age and year.

11. Graph showing cumulative estimates of piping plover chick survival to fledging ( 25 days) along the Garrison Reach by year and for the pre-flood and post-flood periods.

12. Graph showing cumulative estimates of piping plover chick survival to fledging ( 25 days) on Lake Sakakawea by year and for the pre-flood and post-flood periods.

13. Graph showing cumulative estimates of least tern chick survival to fledging (18 days) along the Garrison Reach by year and for the pre-flood and post-flood periods.

14. Graph showing estimates of piping plover adult annual apparent survival by study area and for both study areas

\section{Tables}

1. Number of sampling units and sample sizes by strata, and study areas used for evaluating the effects of the 2011 Missouri River flood on least terns and piping plovers in North Dakota.

2. Explanation of variables used when building Shaffer logistic-exposure models to estimate daily nest survival.

3. Means and standard deviations for the "sdate" (that is, date of nest visit) and "sage" (that is, age of nest at visit) covariates used in nest survival analyses 
4. Explanation of variables used when building Cormack-Jolly-Seber models to estimate daily chick survival

5. Means and standard deviations for the "date" (that is, date a chick was observed) and "age" (that is, age of a chick when observed) covariates used in Cormack-Jolly-Seber models to estimate chick survival

6. Sample of piping plover and least tern nests found and followed for the purpose of nest survival analysis by U.S. Geological Survey crews along the Garrison Reach and Lake Sakakawea

7. Ranked set of logistic-exposure models used to estimate daily piping plover nest survival following the second stage of model selection: examination of the effect of the 2011 Missouri River flood.

8. Ranked set of logistic exposure models used to estimate daily least tern nest survival following the second stage of model selection: examination of the effect of the 2011 Missouri River flood

9. Sample of piping plover and least tern chicks captured and banded by U.S. Geological Survey crews along the Garrison Reach and Lake Sakakawea....

10. Daily detection probability estimates and associated 95-percent confidence intervals for uniquely marked pre-fledge (less than 25 days) and fledged (25+ days) piping plover chicks resighted/recaptured on the Garrison Reach and Lake Sakakawea for all years of the study

11. Ranked set of Cormack-Jolly-Seber models used to estimate daily piping plover chick survival following the third stage of model selection: examination of the effect of the 2011 Missouri River flood

12. Daily detection probability estimates and associated 95-percent confidence intervals for uniquely marked pre-fledge (less than 18 days) and fledged (18+ days) least tern chicks resighted/recaptured on the Garrison Reach for all years of the study

13. Ranked set of Cormack-Jolly-Seber models used to estimate daily least tern chick survival to 30 days following the third stage of model selection: examination of the effect of the 2011 Missouri River flood

14. Sample of piping plover and least tern adults used to estimate annual apparent survival

15. Estimates of minimum breeding population size and breeding population size for piping plovers and least terns nesting along the Garrison Reach before (2006-7) and after (2012-14) the 2011 Missouri River flood

16. Estimates of minimum breeding population size and breeding population size for piping plovers nesting along Lake Sakakawea before (2007-8) and after (2012-14) the 2011 Missouri River flood

17. Number of individual least terns banded between 2012 and 2014 that were missing color bands or alphanumeric bands based on the number of years between recapture 


\section{Conversion Factors}

International System of Units to U.S. customary units

\begin{tabular}{lcl}
\hline \multicolumn{1}{c}{ Multiply } & By & \multicolumn{1}{c}{ To obtain } \\
\hline centimeter $(\mathrm{cm})$ & \multicolumn{1}{c}{ Length } & \\
millimeter $(\mathrm{mm})$ & 0.3937 & inch (in.) \\
meter $(\mathrm{m})$ & 0.03937 & inch (in.) \\
kilometer $(\mathrm{km})$ & 3.281 & foot $(\mathrm{ft})$ \\
kilometer $(\mathrm{km})$ & 0.6214 & mile (mi) \\
meter $(\mathrm{m})$ & 0.5400 & mile, nautical (nmi) \\
\hline & 1.094 & yard (yd) \\
\hline square meter $\left(\mathrm{m}^{2}\right)$ & Area & \\
hectare (ha) & 0.0002471 & acre \\
square hectometer $\left(\mathrm{hm}^{2}\right)$ & 2.471 & acre \\
square kilometer $\left(\mathrm{km}^{2}\right)$ & 2.471 & acre \\
square centimeter $\left(\mathrm{cm}^{2}\right)$ & 247.1 & acre \\
square meter $\left(\mathrm{m}^{2}\right)$ & 0.001076 & square foot $\left(\mathrm{ft}^{2}\right)$ \\
square centimeter $\left(\mathrm{cm}^{2}\right)$ & 10.76 & square foot $\left(\mathrm{ft}^{2}\right)$ \\
square hectometer $\left(\mathrm{hm}^{2}\right)$ & 0.1550 & square inch $\left(\mathrm{ft}^{2}\right)$ \\
hectare (ha) & 0.003861 & section $\left(640 \mathrm{acres}^{2}\right.$ or 1 square mile) \\
square kilometer $\left(\mathrm{km}^{2}\right)$ & 0.003861 & square mile $\left(\mathrm{mi}^{2}\right)$ \\
\hline
\end{tabular}

Temperature in degrees Celsius $\left({ }^{\circ} \mathrm{C}\right)$ may be converted to degrees Fahrenheit $\left({ }^{\circ} \mathrm{F}\right)$ as follows:

${ }^{\circ} \mathrm{F}=\left(1.8 x^{\circ} \mathrm{C}\right)+32$

Vertical coordinate information is referenced to the North American Vertical Datum of 1988 (NAVD 88).

Horizontal coordinate information is referenced to the North American Datum of 1983 (NAD 83).

Altitude, as used in this report, refers to distance above the vertical datum. 


\title{
Demographic Responses of Least Terns and Piping Plovers to the 2011 Missouri River Flood-A Large-Scale Case Study
}

\author{
By Michael J. Anteau, Mark H. Sherfy, Terry L. Shaffer, Rose J. Swift, Dustin L. Toy, and Colin M. Dovichin
}

\section{Abstract}

A catastrophic flood event on the Missouri River system in 2011 led to substantial changes in abundance and distribution of unvegetated sand habitat. This river system is a major component of the breeding range for interior Least terns (Sternula antillarum; "terns") and piping plovers (Charadrius melodus; "plovers"), both of which are Federally listed ground-nesting birds that prefer open, unvegetated sand and gravel nesting substrates on sandbars and shorelines. The 2011 flood inundated essentially all tern and plover nesting habitat during 2011, but it had potential to generate post-flood habitat conditions that favored use by terns and plovers in subsequent years. We compared several tern and plover demographic parameters during the pre-flood and post-flood periods on the Garrison Reach and Lake Sakakawea, North Dakota, to determine how this event influenced these species (both species on the Garrison Reach, and plovers only on Lake Sakakawea). The principal parameters we measured (nest survival, chick survival, and breeding population) showed spatial and temporal variation typical of opportunistic species occupying highly variable habitats. There was little evidence that nest survival of least terns differed between pre- and post-flood. During 2012 when habitat was most abundant on the Garrison Reach and Lake Sakakawea, piping plover nest survival was higher than in any other year in the study, but returned to rates comparable to pre-flood years in 2013. Chick survival for terns on the Garrison Reach and plovers on Lake Sakakawea showed a similar pattern to plover nest survival, with the 2012 rate exceeding all other years of the study, and the remaining pre-flood and post-flood years being generally similar but slightly higher in post-flood years. However, plover chick survival on the Garrison Reach in 2012 was similar to preflood years, and increased annually thereafter to its highest rate in 2014. Although wide confidence intervals precluded firm conclusions about flood effects on breeding populations, the general pattern suggested lower populations of plovers but higher populations of least terns immediately after the flood. Despite near total absence of breeding habitat on either study area during the flood of 2011, populations of both species persisted after the flood due to their propensity to disperse and/or forgo breeding for at least a year. Tern and plover populations have similarly persisted and recovered after the flood, but their mechanisms for persistence likely differ. Data on tern dispersal is generally lacking, but they are thought to show little fidelity to their natal grounds, have a propensity to disperse potentially long distances, and routinely forgo breeding until their second year, thus a lost opportunity to breed in a given area may be easily overcome. Plovers exhibit stronger demographic ties to the general area in which they previously nested, yet they occupy much broader nesting habitat features than terns and exploit three major landforms in the Dakotas (free-flowing rivers, reservoir shorelines, and wetland shorelines). Consequently, dispersal to and from non-Missouri River habitats and potential to exploit non-traditional habitats likely sustained the Northern Great Plains population through the flood event. Terns and plovers normally occupy similar habitats on the Missouri River and both species experienced similar loss of a breeding season due to the flood. Persistence of these populations after the flood underscores the importance of understanding their unique demographic characteristics and the context within which the Missouri River operates.

\section{Introduction}

Least terns (Sternula antillarum) and piping plovers (Charadrius melodus) nest in spatially and temporally variable habitats in the North American midcontinent. It has been proposed that periodically high reproductive rates, long life spans, adaptation to the use of variably available nesting habitat, and high dispersal capabilities of these species make them especially well-suited to colonizing newly established habitats (Catlin and others, 2010; Anteau and others, 2014a,b). The Federal listing status of interior least terns (endangered; hereafter referred to as "least terns" or "terns") and northern Great Plains piping plovers (threatened; hereafter referred to as "plovers") has motivated substantial work to understand ecological relationships between the birds and their nesting habitats. The Missouri River system supports nesting populations and is an important component of recovery efforts for both species. Rapid colonization of novel habitats, in the form 
of constructed sandbars or dynamic reservoir shorelines, has been documented through directed research on the Missouri River (Catlin, 2009; Sherfy and others, 2012a; Anteau and others, 2014a). Pulses of productivity lasting several years have occurred after colonization events, facilitating persistence of populations at larger regional scales (Catlin, 2009; Cohen and others, 2009).

In a naturally functioning river system, sediment is eroded, transported, and deposited by seasonally variable flows, creating and maintaining emergent sandbars. Spring pulses are particularly important ecological events because they can transport substantial sediment loads and can scour vegetation from previously created sandbars. Construction and operation of dams on the Missouri River has attenuated peak spring flows, resulting in declines in abundance and quality of unvegetated sandbar habitats favored by nesting terns and plovers. The Missouri River flood of 2011 (hereafter also referred to as "the flood") was a historically and ecologically significant event in which spring and summer flows far exceeded all historical records for the post-dam era; all main-stem dams were releasing flood flows simultaneously and reservoirs were at their highest recorded elevations. The magnitude of this event surpassed the 1997 flood, which was previously considered the modern-era benchmark for unprecedented high spring flows (Dixon and others, 2011). Consequently, some natural hydrologic processes were mimicked during the flood in a way that is unexpected on a regulated river, and the resulting flow induced substantial habitat alteration and markedly increased sandbar habitat available for use by terns and plovers.

Outcomes of major flood events are visually striking in flowing river systems, where marked increases in flow and stage can have catastrophic effects on people, infrastructure, and ecological communities. Dams on a regulated river system control downstream flow and stage as well as upstream water level. Thus, catastrophic events such as the Missouri River flood of 2011 can also have profound effects on the impounded river reaches, particularly when the event's magnitude exceeds historical norms for water level. Impounded and flowing segments of regulated rivers are often viewed as discrete and independent units, although they may share some biological attributes for which flood effects should be evaluated simultaneously. Nesting terns and plovers are two such attributes, and this study seeks to provide context for flood effects on terns and plovers across the continuum of Missouri River nesting habitats (riverine sandbars and reservoir shorelines).

Prior to the flood, several studies generated estimates of tern and plover demographic parameters when the birds occupied either engineered or degraded riverine habitats, periodically at densities sufficiently high enough to impair productivity (Catlin, 2009; Sherfy and others, 2012b; Shaffer and others, 2013; Anteau and others, 2014c). Habitat distribution and abundance on the post-flood river more closely represent natural conditions than any other time in the post-dam era. The availability of nesting and foraging habitat is the principal factor affecting productivity and abundance of terns and plovers (Anteau and others, 2014a,c), and managing habitat is the principal tool available to managers for recovery of tern and plover populations (Sherfy and others, 2008). Consequently, understanding how the birds responded numerically and demographically to this major habitat alteration is critical to future river management. The immediate post-flood years were also an unprecedented opportunity to document demography and vital rates of the birds in nearly natural nesting habitat conditions, providing previously unavailable context for understanding their responses to a spatially and temporally variable system. Directed studies also have examined causative mechanisms driving demographics, such as food limitation and predation, on natural and constructed sandbars on the pre-flood river, but it is not known whether these same mechanisms remain important on the post-flood river. Also, several studies developed predictive and explanatory models for plover habitat, distribution, and nest and chick survival in response to reservoir water-level fluctuations (Anteau and others, 2012a,b; 2014a,b,c). However, those studies followed a long successive drawdown when lake levels were low. It is unclear if those models would be appropriate following reservoir refilling and when the reservoir is at levels above that observed in previous studies.

We also sought to evaluate the viability of some new research techniques. Substantial effort has gone into marking and resighting adult piping plovers on the Missouri River, resulting in enhanced knowledge of survival rates and fidelity to breeding and wintering areas (Catlin, 2009; Roche and others, 2010). Although substantial effort also has gone into banding adult least terns to address local questions about habitat use and movements (Sherfy and others, 2012b; Toy and others, 2017), there has been comparatively little effort into resighting adult terns. Knowledge of annual survival rates and fidelity is equally important for management of terns as for plovers, but there is uncertainty about whether reasonable resighting rates of marked adult terns can be readily obtained (Toy and others, 2017).

\section{Objectives}

The primary goal was to document demographic responses of terns and plovers to the habitat alterations induced by the 2011 Missouri River flood by comparing vital rates measured in pre-flood and post-flood systems for the Garrison Reach and Lake Sakakawea, including the following:

1. Estimate survival to hatch of least tern and piping plover nests and compare to pre-flood estimates.

2. Estimate survival to fledging age of least tern and piping plover chicks and compare to pre-flood estimates.

3. Estimate annual adult survival of piping plovers and compare to pre-flood estimates.

4. Estimate annual breeding population of least terns and piping plovers and compare to pre-flood estimates. 
The secondary goal was to support future research and decision making for implementation of management actions by providing preliminary information on bird responses to management actions under the river's new conditions, which includes the following:

5. Evaluate feasibility of mark-resight techniques to estimate site fidelity and annual survival of adult least terns.

\section{Study Areas}

We selected two study areas for field work during 2012-14 - one river reach (Garrison Reach) and one reservoir (Lake Sakakawea) (fig. 1). When available, we compiled previously collected data for the same study areas during pre-flood years (2006-9). Both study areas have been extensively described previously (Sherfy and others, 2008; Shaffer and others, 2013), and both were affected markedly by the Missouri River flood of 2011. The flood event had a temporally discrete effect on riverine and reservoir habitat, although effects on habitat could vary over a series of years. In both areas, the immediate effect of a catastrophic flood is that nesting habitat is eliminated due to inundation. Subsequent decreases in water level would expose new bare-substrate habitat that could be exploited by plovers and terns. In the case of reservoirs, this would consist of shoreline where vegetation had been removed by inundation (Anteau and others, 2012a; Anteau and others, 2014b), and on riverine habitat, it would consist of newly deposited sandbars or existing sandbars that had been scoured of vegetation (Catlin and others, 2010). In both cases, the flood-created habitat could potentially be available to nesting birds for several years, although degradation processes such as subsequent inundation, vegetation regrowth, and erosion would vary spatially.

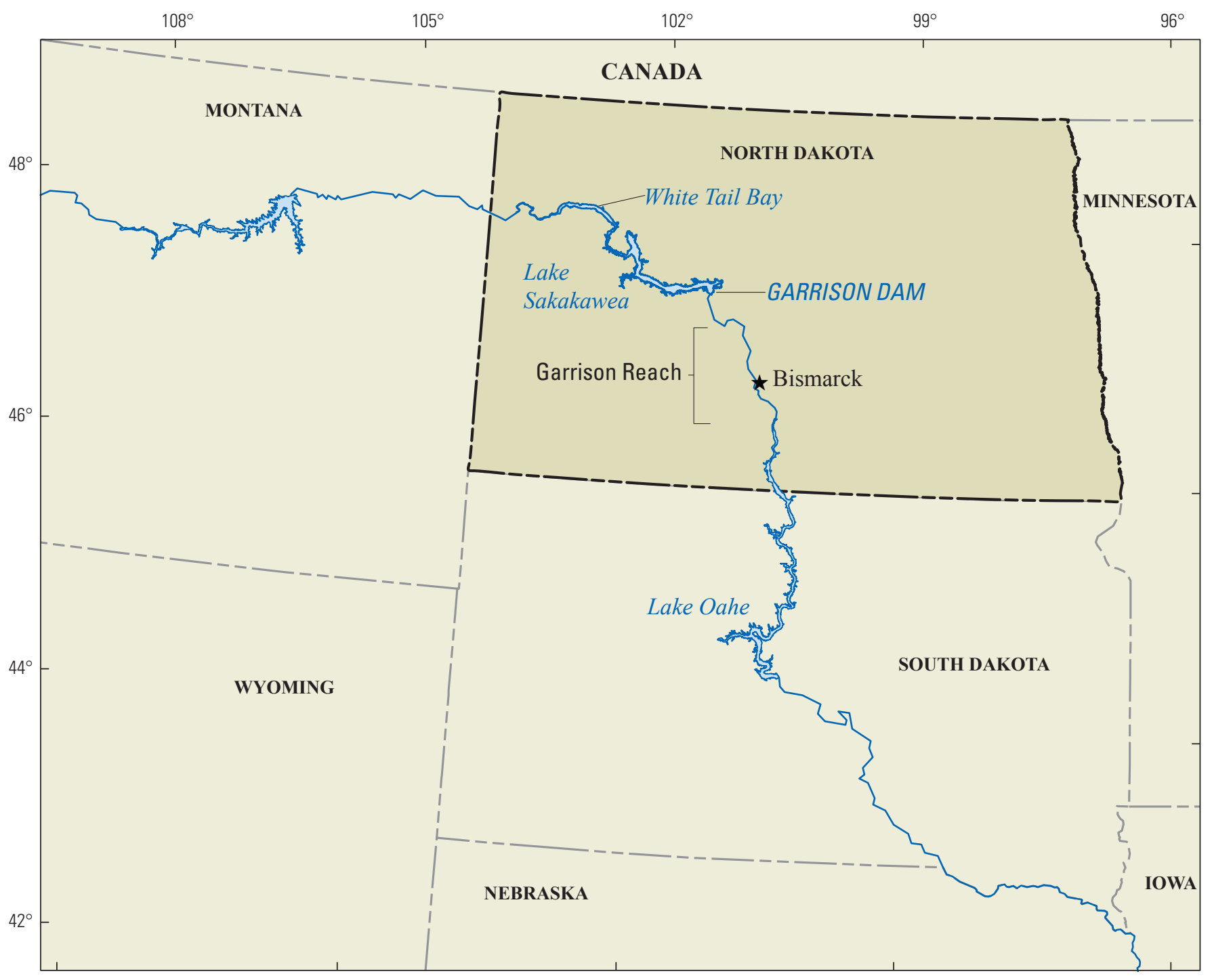

Figure 1. Flood science study area during 2006-9 and 2012-14. 


\section{Garrison Reach}

This study area was defined as the 86 river miles (RM) of sandbar and shoreline habitat extending from the Garrison Dam, North Dakota (RM 1390) to the headwaters of Lake Oahe, N. Dak. (RM 1304) (fig. 1). U.S. Geological Survey (USGS) crews had done field work on plovers and terns previously on this river reach in 2006 and 2007 (Shaffer and others, 2013). This study area is used for nesting by plovers and terns.

\section{Lake Sakakawea}

This study area was defined as the $178 \mathrm{RM}$ of reservoir habitat extending northwest from the Garrison Dam, N. Dak., to White Tail Bay, N. Dak. (fig. 1). USGS crews had done field work on plovers and terns previously in this study area during 2006-9 (Anteau and others, 2012a,b; Shaffer and others, 2013). This study area is predominantly used for nesting by plovers with only occasional use by terns.

\section{Sampling}

A complete census of terns and plovers on all available nesting habitat in both study areas was impractical. We employed a probability-based sampling effort on GRR and SAK during 2012-14 to obtain unbiased population and demographic estimates while remaining consistent with pre-flood sampling methodology. Under a probability-based sampling effort, data are collected on a sample of units that represents a larger whole. In this report, these sampling units were spatially defined and included both study areas without overlap (Cochran, 1977; Shaffer and others, 2013).

Missouri River shoreline and sandbar habitats are highly dynamic, varying extensively in distribution and abundance within and among years. Because of their ephemeral nature, defining individual shoreline and sandbar habitats as "sampling units" is inappropriate (Sherfy and others, 2008). Beginning in 2006, we addressed this challenge by dividing each study area into sampling units that are spatially defined and invariant (Shaffer and others, 2013). Unit lengths differed by study area because of differences in habitat structure and bird density; the intent was that a crew would be able to completely search two units of habitat for nests in a single day. We divided the river reach (GRR) into 4-RM sampling units $(N=22)$ defined by the river bank as the outer edge during 2006-7. For 2012-14, we divided GRR into 3-RM sampling units $(N=28$; table 1$)$. We divided the reservoir (SAK) shoreline into sampling units $(N=545)$ of approximately 2 kilometers $(\mathrm{km})$ using an intermediate lake level at an elevation of 554 meters $(\mathrm{m})$ (more information in Shaffer and others, 2013); our available population of Lake Sakakawea sampling units varied annually due to water-level fluctuations inundating island units and refinement of the definition of suitable habitat (table 1; Anteau and others, 2014a).

We further refined our probability-based sampling effort by classifying our sampling units into one of several strata (that is, groups sharing similar properties). If the differences between the stratified groups are large, then dividing a sample into strata and sampling within a stratum can increase the overall precision of estimates (Shaffer and others, 2013;

Table 1. Number of sampling units and sample sizes by strata, and study areas used for evaluating the effects of the 2011 Missouri River flood on least terns and piping plovers in North Dakota.

[ $N$, number of sampling units; $n$, sample sizes; GRR, Garrison Reach; SAK, Lake Sakakawea; --, no data]

\begin{tabular}{|c|c|c|c|c|c|c|c|c|c|}
\hline \multirow{2}{*}{ Study area } & \multirow{2}{*}{ Year } & \multicolumn{2}{|c|}{ Low strata } & \multicolumn{2}{|c|}{ Medium strata } & \multicolumn{2}{|c|}{ High strata } & \multicolumn{2}{|c|}{ Total } \\
\hline & & $N$ & $n$ & $N$ & $n$ & $N$ & $n$ & $N$ & $n$ \\
\hline \multirow[t]{3}{*}{ GRR } & 2006 & 6 & 3 & 5 & 4 & 10 & 10 & 21 & 17 \\
\hline & 2012 & 9 & 5 & 11 & 6 & 8 & 3 & 28 & 14 \\
\hline & 2013 & 13 & 4 & 8 & 7 & 8 & 5 & 26 & 16 \\
\hline \multirow[t]{4}{*}{ SAK } & 2006 & 403 & 7 & 88 & 5 & 53 & 5 & 544 & 17 \\
\hline & 2007 & 403 & 5 & 88 & 7 & 53 & 18 & 544 & 30 \\
\hline & 2008 & 403 & 5 & 88 & 7 & 53 & 18 & 544 & 30 \\
\hline & 2009 & 403 & 24 & 88 & 6 & 53 & 5 & 544 & 35 \\
\hline
\end{tabular}


Cochran, 1977). During pre-flood years (2006-9), we classified our sampling units into one of three strata based on the number of plover and tern nests found in each unit according to the U.S. Army Corps of Engineers tern and plover monitoring data (Shaffer and others, 2013). Beginning in 2012, we used a USGS-created predictive habitat model informed by water levels, vegetation colonization rates, and topography similar to that of Anteau and others $(2014 a, b)$ to stratify our sampling units. For all years, we excluded RM 1388-1391 from our GRR sample because these RMs had no history of emergent sandbar habitat; this brought our GRR study area to a total of $N=214$-RM sampling units during 2006-7 and $N=28$ 3-RM sampling units during 2012. During 2013-14 we excluded an additional two 3-RM sampling units on GRR because they did not contain suitable breeding habitat, bringing our total to $N=26$. Similarly, not all of the original 545 sampling units on SAK were considered viable nesting habitat for plovers or terns. During the course of our work on this reservoir we were able to further refine the total sampling units through proximity to bluffs (that is, $25-\mathrm{m}$ rise within $250 \mathrm{~m}$ of shoreline; Anteau and others, 2014a), an opportunistic habitat survey of more than 100 sampling units during 2013, historical nest-monitoring data, and USGS nesting data (table 1). We used Neyman allocation to optimally distribute our annual sampling effort among the three strata (Cochran, 1977).

\section{Field Methods}

During all years we intensively (2-3 surveys per sample unit per week) surveyed for plover and tern nests and marked chicks along a subset of sampling units in both study areas. Beginning in 2012, we expanded our surveys to include marked adults of both species. We recorded observations of uniquely marked adults when visiting intensively surveyed sampling units (hereafter referred to as "on-segment" sampling units) as well as when visiting sampling units not included in our sample of intensively surveyed units (hereafter referred to as "off-segment" sampling units). Although we collected data on least terns on Lake Sakakawea throughout the study and include these data in this report, our sample sizes were not sufficient for statistical analysis.

\section{Nests}

We defined a nest as a scrape or depression containing at least one egg. Crews of 2-4 individuals searched for nests on all available nesting habitat at 2-3-day return intervals from mid-April (the arrival of piping plovers to the study areas) through mid-August (the end of least tern nest initiation). Crews searched for nests by walking grid patterns through available nesting habitat (both GRR and SAK) or using behavioral cues of adults (predominantly on SAK). During all subsequent visits to a sample unit, crews revisited all previously found nests to record status and searched all available habitat including any new habitat that had become available. Crews only searched during suitable weather conditions, as identified in our U.S. Fish and Wildlife Service Threatened and Endangered Species Permit.

When a nest was found, we estimated the incubation stage by floating one or two eggs (Mabee and others, 2006). We used incubation stage to estimate nest initiation date by backdating from the discovery date and, excluding the first egg laid, assuming one egg was laid per day for terns and every other day for plovers. We estimated hatch dates by assuming a 25-day incubation period for plovers and a 20-day incubation period for terns (Shaffer and others, 2013). Nests were visited more frequently near the estimated hatch date to decrease the uncertainty associated with nest fating and increase the probability of banding fully hatched chicks in the bowl (Grant and others, 2005; Shaffer and others, 2013).

Nests were assigned one of four fates (successful, probable successful, failed, unknown) based on evidence in and around the nest bowl (Mabee, 1997). A nest was only fated as "successful" if at least one live chick was observed in the nest bowl. If other evidence of hatching (Page and others, 1985; Dirks, 1990) was found at the nest bowl (for example, eggshells, pipping fragments, chick droppings, chick tracks, or chicks near the nest bowl) we fated the nest as "probable successful." Nests were classified as "failed" if eggs were found destroyed or missing but could not have hatched based on the estimated incubation stage at last visit. If circumstances were unclear, we fated the nest as "unknown." We recorded the date that evidence for the nest fate was collected and considered this the "nest fating date." For our later analyses, we combined "successful" and "probable successful" into one category; nests of "unknown" fate were excluded from analyses.

\section{Chicks}

The USGS crews visited nests daily near the estimated hatch date to band chicks in the nest bowl. Crews captured chicks by hand or using butterfly nets. Because of permitting restrictions, crews were not always able to band all chicks in a brood, and in these situations we adopted a sampling strategy in which 3 chicks were banded in broods of 4-2 chicks from broods of 3 , and 1 chick from a brood of 2 chicks. If there was only one chick present, we banded that chick.

Chicks of both species were marked using a metal band and a combination consisting of (1) several individual color bands (plovers: 2006-9, 2012; terns: 2006-7, 2012), (2) a single yellow alphanumeric band (terns: 2013-14), or (3) a yellow alphanumeric flag (plovers: 2013-14). Piping plovers were banded with size $1 \mathrm{~A}$ aluminum metal bands placed above the tibiotarsal joint and combinations of as many as four plastic color bands (below the tibiotarsal joint) and a plastic flag or alphanumeric flag (above the tibiotarsal joint opposite from the metal band). Least tern chicks were banded with a size $1 \mathrm{~A}$ stainless steel band placed below the tibiotarsal joint 
along with as many as three color bands (two placed below the tibiotarsal joint and one placed above) or a single alphanumeric band (below the tibiotarsal joint opposite from the metal band).

Following banding, crews visited sites with marked chicks at 2-3-day intervals and resighted uniquely marked individuals by reading band combinations through spottingscopes, via digital cameras, or by recapturing chicks by hand and reading their bands. Crews continued to visit sites at 2-3-day intervals until there were no additional plovers or terns available to be resighted or until the end of the field season.

\section{Adults}

The banding of adult terns and plovers was predominantly concentrated to "on-segment" sampling units where nests and chicks were already being followed at 2-3-day intervals; however, because adults can easily move among miles of river and reservoir shoreline habitat, adults were often banded when nests were found at nearby "off-segment" locations. We captured adults using a combination of remotely operated bow-net traps (used mostly to capture adult least terns) and remotely operated walk-in traps (used exclusively to capture adult piping plovers). We only trapped under permitted weather conditions and after at least 2 days of incubation. During trapping events, live eggs were replaced with artificial eggs to minimize the potential for egg damage.

Adult piping plovers were banded with size $1 \mathrm{~A}$ aluminum metal bands placed above the tibiotarsal joint and combinations of as many as four plastic color bands (below the tibiotarsal joint) and a plastic flag or alphanumeric flag (above the tibiotarsal joint opposite from the metal band). Adult least terns were banded with size 1A stainless steel bands placed below the tibiotarsal joint along with as many as three color bands (below the tibiotarsal joint) or a single alphanumeric band (below the tibiotarsal joint opposite from the metal band).

When visiting a site, the crews recorded the band combinations of all birds observed, the degree of completion with which they read the band combination, and the method used to resight the individual. If no adults were observed during a site visit, crews simply recorded the date, time, location, and purpose of the site visit.

\section{Data Analysis}

\section{A Priori Predictions}

Prior to analyses to estimate nest and chick survival in the periods before (2006-9) and after the flood (2012-14), we compiled a set of predictions as to how survival could have responded to the flood. For each prediction we describe possible effects of the flood and how this effect would be modeled. We then built and evaluated models that reflected these predictions; we present examples of what these models would look like in the context of a nest survival analysis. We used general terminology so that predictions could be applied to nest survival to hatch and chick survival to fledge. A description of each variable used when building nest survival models is shown in table 2. Data analyzed for this study are available as a USGS data release (Sherfy and others, 2018).

Table 2. Explanation of variables used when building Shaffer logistic-exposure models to estimate daily nest survival.

[GRR, Garrison Reach; SAK, Lake Sakakawea]

\begin{tabular}{|c|c|}
\hline Variable & Description \\
\hline constant & Single-level, categorical; daily survival is constant across date and age. \\
\hline firstyear & $\begin{array}{l}\text { Single-level, categorical; first year following the } 2011 \text { flood (2012) } \\
\text { different than other years. }\end{array}$ \\
\hline floodtrend & Continuous; years following the flood follow a log-linear trend. \\
\hline otheryear & $\begin{array}{l}\text { Single-level, categorical; second and third years following the } 2011 \text { flood (2013-14) } \\
\text { different than other years. }\end{array}$ \\
\hline postflood & Single-level, categorical; years following the 2011 flood (2012-14). \\
\hline preflood & Single-level, categorical; years prior to the 2011 flood (2006-09). \\
\hline sage & Continuous; age of the nest (days) at a nest visit. \\
\hline sdate & Continuous; date the nest was visited. \\
\hline studyarea & Two-level, categorical; location of the nest (GRR, SAK). \\
\hline year & Multilevel, categorical; year the nest was initiated $(2006-09,2012-14)$. \\
\hline
\end{tabular}


Prediction: There is no detectable effect of the flood on survival estimates.

1. Survival varies by study area but not by year, for example $S$ (studyarea)

Prediction: There is sufficient annual variation in survival estimates to mask an effect specific to the flood.

2. Survival varies by year differently for each study area, for example $S$ (studyarea*year)

3. Survival varies by year in the same way for each study area, for example $\mathrm{S}$ (studyarea + year)

Prediction: There is a constant effect of the flood on survival in all post-flood years.

4. Survival in the pre-flood years is different than survival in the post-flood years; the magnitude of the flood effect differs by study area, for example $S$ (studyarea* preflood + studyarea*postflood)

5. Survival in the pre-flood years is different than survival in the post-flood years; there is no difference in the effect of the flood by study area, for example $S$ (preflood + postflood)

Prediction: There is an immediate effect of the flood on survival, but in the years following the flood the response follows a log-linear trend.

6. Survival in pre-flood years varies by study area and is different than survival in post-flood years (which also vary by study area); survival follows study area dependent log-linear trends in post-flood year, for example $S$ (studyarea*preflood + studyarea*postflood*floodtrend)

7. Survival in pre-flood years is different than postflood years and survival follows a log-linear trend in post-flood year, for example, $S$ (preflood + postflood*floodtrend)

Prediction: There is an effect of the flood on survival only in the first year following the flood (that is, survival during all other "post-flood" years resembles the pre-flood period).

8. Survival in the first year after the flood is different than all other years; survival varies by study area in the first year after the flood and following a separate pattern in all other years, for example $S$ (studyarea*firstyear + studyarea*otheryear)

9. Survival in the first year after the flood is different than all other years, for example $S$ (firstyear + otheryear)

Prediction: There is an effect of the flood on survival in all post-flood years, but the effect is most pronounced for the year immediately following the flood.

10. Survival in pre-flood years varies by study area, survival in the first year post-flood is different from pre-flood years and varies by study area, survival in all other post-flood years is also different than previous years and varies by study area, for example, $S$ (studyarea*preflood + studyarea*firstyear + studyarea*otheryear)

11. Survival in pre-flood years is different than in the first year post-flood and survival in all other post-flood years is different than in all previous years, for example, $S($ preflood + firstyear + otheryear)

\section{Nest Survival}

We built logistic-exposure models in program $\mathrm{R}$ (Shaffer, 2004; R Core Team, 2014) to estimate the daily probability of survival $(S)$ for plover and tern nests on GRR and SAK. We analyzed nest-visit data for each species separately and followed a three-step model-selection approach.

Prior to investigating our predictions of how nest survival may have changed following the flood, we sought to account for variation in nest survival due to nest age, seasonal date, and study area (see table 3 for the means and standard deviations [SDs] for these estimates). For the first model-selection step, we built models that estimated survival in relation to study area only (note that nest survival for LETE was only analyzed for a single study area: GRR), nest age at visit ("sage") only, nest visit date ("sdate") only, both sage and sdate, and all combinations of sage and sdate by study area. A description of variables used in nest survival analysis is shown in table 3. We ranked models using Akaike's information criterion corrected for small sample size (AICc) and selected the model with the lowest AICc for the next step of model selection.

Using the top-supported model from our first modelselection step, we next built models that reflected our 11 a priori predictions describing how nest survival might have changed following the flood for plovers and terns. In this second model-selection step, we again built and ranked models separately for plovers and terns.

We reasoned that annual changes in the effect of nest age and date on nest survival could underlie the response patterns of nest survival following the flood. Thus, for our third modelselection step, we built a series of post-hoc models investigating whether there was support for changes in annual patterns of both covariates. We constructed a similar set of models to the models built in the first step, but this time included an interaction with year as well as study area for both sage and sdate. We ranked models using AICc and selected the model with the lowest AICc for the next step of model selection.

We computed cumulative nest survival by taking the product of daily nest survival estimates out to 21 days for least tern nests and out to 35 days for piping plover nests. We estimated associated standard errors (SE) using the Delta method and package "msm" (Jackson, 2011). We used a log-odds transformation of the daily survival probability to compute associated 95-percent confidence intervals to ensure estimates were bounded between 0 and 1 (Armstrong and others, 2002). 
Table 3. Means and standard deviations for the "sdate" (that is, date of nest visit) and "sage" (that is, age of nest at visit) covariates used in nest survival analyses. Also reported are the means and standard deviations for estimated initiation date and nest age at discovery for piping plover (PIPL) and least tern (LETE) nests on the Garrison Reach of the Missouri River (LETE: 2006-7, 2012-14; PIPL: 2006-7, 2012-14) and Lake Sakakawea (LETE: 2007-09, 2012-14; PIPL: 2006-9, 2012-14).

[sdate, date of nest visit; sage, age of nest at visit]

\begin{tabular}{lllc}
\hline \multicolumn{1}{c}{ Species } & \multicolumn{1}{c}{ Variable } & Mean & $\begin{array}{c}\text { Standard } \\
\text { deviation } \\
\text { (days) }\end{array}$ \\
\hline Piping plover & sdate & June 14 & 17.2 \\
& initiation date & May 30 & 15.1 \\
& sage & 16 days & 9.0 \\
& nest age at discovery & 5.5 days & 5.0 \\
Least tern & sdate & June 26 & 12.7 \\
& initiation date & June 16 & 11.4 \\
& sage & 11 days & 6.0 \\
& nest age at discovery & 3.6 days & 3.8 \\
\hline
\end{tabular}

\section{Chick Survival}

We built Cormack-Jolly-Seber (CJS) models using package "RMark" in program R and MARK (Laake, 2013; White and Burnham, 1999) to estimate the daily probability of apparent survival $(\varphi)$ and detection $(p)$ for tern and plover chicks marked and followed on GRR and SAK. The probability of true survival is generally confounded with the probability of emigration from a site when estimating apparent survival using CJS. However, for unfledged chicks, the probability of emigration from a site is essentially 0 , and thus we can interpret all apparent survival estimates made prior to fledging age as true survival estimates.

We analyzed tern and plover mark-recapture data separately following a four-step model-selection approach. We used program RELEASE to calculate estimates of over-dispersion $(\hat{c})$ separately for the tern and plover capture histories.

We created age-structured capture histories for both species that consisted of 30 occasions (that is, hatch day-age 29 days). If a chick was observed by USGS crews, this occasion was coded as "1." If USGS crews visited the site at which a chick had been banded prior to an age at which we would have considered that chick fledged (terns: 18 days, plovers: 25 days) and the chick was not observed, then this occasion was coded as " 0 " (for example, if crews visited the site where tern chick A was banded on occasion 17 and the chick was not seen, the occasion was coded as "0"). After chicks fledge (that is, can fly) they are no longer restricted to the site at which they were banded and could reasonably be seen anywhere on a several RM stretch. Thus, if USGS crews visited any site in the study area after an age at which a chick was considered fledged and the chick was not observed, this occasion was also coded as " 0 " (for example, if crews were on GRR on occasion 25 for tern chick A and the chick was not seen, the occasion was coded as a "0"). If USGS crews did not visit a site of an unfledged chick, this occasion was coded as "." and censored from the analysis (for example, if crews did not visit the site at which tern chick A was banded on occasion 10, then the chick was not seen because nobody was there to see it and the occasion was coded as “.”).

We were primarily interested in estimating daily apparent survival probabilities for both species. Thus, our first modelselection step focused on parameterizing our model of detection probability (Lebreton and others, 1992). In all models of detection, we accounted for differences in detection based on whether or not a chick was older than the fledge age for the species in question (that is, "post $F$ " compared to " $d 2 t o F$ "). We built models in which detection varied by all combinations of chick age ("age"), the year of the study ("year"), and the study area ("studyarea"). In all cases, we modeled studyarea, year, and age effects separately for pre-fledge and post-fledge stages. We ranked models using Akaike's information criterion corrected for small sample size (AICc) (or small sample size and overdispersion (QAICc) when appropriate), and selected the model with the lowest AICc or QAICc as our parameterization for detection probability when building subsequent models for apparent survival. Under all parameterizations for detection probability, apparent survival was modeled as $(\varphi[$ postF*year*studyarea + age*year*studyarea*d1 toF $])$, where "*” indicates an interaction and "+" indicates an additive relationship (note that GRR was the only study area for least terns). A description of variables used when building models for chick survival is shown in table 4 .

Prior to investigating our predictions of how daily chick survival may have changed following the flood, we sought to account for variation in chick survival due to chick age, seasonal date, and study area (see table 5 for mean and SDs for these covariates). Additionally, in all models of apparent survival, we accounted for differences in survival based on whether or not a chick was older than the fledge age for the species in question (that is, "post $F$ " compared to "dl to $F$ "). For our second model-selection step, we built models that estimated survival in relation to study area only, chick age at visit ("age") only, chick visit date ("date") only, both age and date, and all combinations of age and date by study area. In all cases, we modeled studyarea, date, and age effects separately for pre-fledge and post-fledge stages. We ranked models using QAICc, and selected the model with the lowest QAICc as our parameterization of apparent survival, which included parameters for detection probability that we identified during the first step. 
Table 4. Explanation of variables used when building Cormack-Jolly-Seber models to estimate daily chick survival.

[GRR, Garrison Reach; SAK, Lake Sakakawea]

\begin{tabular}{|c|c|}
\hline Variable & Description \\
\hline age & Continuous, occasion-specific; age of the chick (days) when observed. \\
\hline date & Continuous, occasion-specific; date the chick was observed. \\
\hline constant & Single-level, categorical; daily survival is constant across date and age. \\
\hline postF & Single-level, categorical; daily survival or detection is different following fledging age. \\
\hline d1 toF & Single-level, categorical; daily survival is different prior to fledging age. \\
\hline $\mathrm{d} 2 \mathrm{toF}$ & Single-level, categorical; daily detection is different prior to fledging age. \\
\hline studyarea & Two-level, categorical; location where the chick was banded (GRR, SAK). \\
\hline year & Multilevel, categorical; year the chick hatched $(2006-09,2012-14)$. \\
\hline preflood & Single-level, categorical; years prior to the 2011 flood (2006-09). \\
\hline postflood & Single-level, categorical; years following the 2011 flood (2012-14). \\
\hline floodtrend & Continuous; years following the flood follow a log-linear trend. \\
\hline firstyear & $\begin{array}{l}\text { Single-level, categorical; first year following the } 2011 \text { flood (2012) different than } \\
\text { other years. }\end{array}$ \\
\hline otheryear & $\begin{array}{l}\text { Single-level, categorical; second and third years following the } 2011 \text { flood (2013-14) } \\
\text { different than other years. }\end{array}$ \\
\hline
\end{tabular}

Table 5. Means and standard deviations for the "date" (that is, date a chick was observed) and "age" (that is, age of a chick when observed) covariates used in Cormack-JollySeber models to estimate chick survival. Also reported are the means and standard deviations for the number of visits in the encounter history, estimated hatch date, and age at banding for piping plovers (PIPL) and least terns (LETE) captured and banded along the Garrison Reach of the Missouri River (LETE: 2006-7, 2012-14; PIPL: 2007, 2012-14) and Lake Sakakawea (PIPL: 2006-9, 2012-14).

\begin{tabular}{lllc}
\hline Species & \multicolumn{1}{c}{ Variable } & Mean & $\begin{array}{c}\text { Standard } \\
\text { deviation } \\
\text { (days) }\end{array}$ \\
\hline Piping plover & Visits & 14.9 & 4.3 \\
& Date & July 6 & 15.1 \\
& Hatch date & June 28 & 14.8 \\
& Age & 9 days & 5.5 \\
Least tern & Age at banding & 2.5 days & 3.5 \\
& Visits & 19.7 & 4.3 \\
& Date & July 12 & 10.2 \\
& Hatch date & July 4 & 8.7 \\
& Age & 8 days & 5.5 \\
& Age at banding & 1.8 days & 2.7 \\
\hline
\end{tabular}

Using the top-supported model from our second model-selection step, we next built models that reflected our 11 a priori predictions describing how chick survival might have changed following the flood for plovers and terns. In this third model-selection step, we again built and ranked models separately for plovers and terns.

We reasoned that annual variation in the effect of chick age and date on chick survival could underlie the response patterns of chick survival following the flood. Thus, for our fourth model-selection step, we built a series of post-hoc models investigating whether there was support for changes in annual patterns of both covariates. We constructed a similar set of models to the models built in the second step, but this time included an interaction with year as well as study area for both age and date. We again built and ranked models separately for plovers and terns.

We computed cumulative chick survival to fledging by taking the product of daily chick survival estimates out to 18 days for least tern chicks and out to 25 days for piping plover chicks. We estimated associated standard errors using the Delta method and package "msm" (Jackson, 2011). We used a log-odds transformation of the daily survival probability (Armstrong and others, 2002) to compute associated 95-percent confidence intervals to ensure estimates were bounded between 0 and 1 . 


\section{Adult Survival}

We built CJS models using package "RMark" in program R and MARK (Laake, 2013; White and Burnham, 1999) to estimate the annual probability of apparent survival $(\varphi)$ and detection $(p)$ for terns and plovers marked or resighted as adults on GRR and SAK during 2012-15. As previously mentioned, the probability of true survival is generally confounded with the probability of emigration from a site when estimating apparent survival using CJS. Even though USGS crews were present in an additional two study areas in 2014, we restricted our mark-recapture analysis to individuals resighted on GRR and SAK. Based on sightings outside this study area by USGS crews of plovers originally banded on GRR and SAK, we knew that our estimates of apparent survival would reflect permanent emigration out of the study area.

We completed two separate analyses to estimate annual apparent survival and detection for piping plovers.

- In the first analysis, we built four-occasion markrecapture histories without regard to the study area in which a plover was seen (that is, as long as it was seen in either GRR or SAK in a year it was coded as "1"). The results of this analysis would provide an overall estimate of apparent survival and detection for the entire study area.

- In the second analysis, we built separate four-occasion mark-recapture histories for plovers observed on SAK and GRR. In this analysis, there were two groups to reflect the two study areas; however, unlike the first analysis, where each marked individual only has one capture history, an individual could have two capture histories if it was observed in multiple study areas. The results of this analysis would give us study-areaspecific estimates of apparent survival and detection. In both analyses, we included resights/recaptures of adult plovers only.

We completed a single analysis to estimate annual apparent survival and detection for least terns. We built four-occasion mark-recapture histories without regard to the study area in which a tern was seen or captured (that is, as long as it was seen in either GRR or SAK in a year it was coded as "1"). We included resights/recaptures of adult terns only.

We analyzed tern and plover mark-recapture data separately following a two-step model-selection approach. We calculated estimates of over-dispersion separately for the tern and plover capture histories using the median $\hat{c}$ test in program MARK.

For all analyses we built simple models in which detection and apparent survival were either constant or varied by study area (where appropriate). We ranked models using AICc and QAICc, and selected the model with the lowest QAICc as our parameterization.

\section{Breeding Population Size}

We used the minimum breeding population (MINBPOP) estimator developed and described by Shaffer and others (2013) to estimate the breeding population (BPOP) of adult piping plovers (GRR: 2006-7, 2012-14; SAK: 2007-8, 2012-14) and least terns (GRR: 2006-7, 2012-14). We defined the BPOP for a study area as the number of adults in the study area that attempted to initiate at least one nest. The $\mathrm{BPOP}$ is an unbiased estimate of breeding population size (that is, corrected for detection).

To generate a BPOP estimate for each study area, we had to first define a metric that represented the absolute MINBPOP in a study area based on our periodic nest visits. This metric (MINBPOP) was based on the sum of the number of active nests, recently failed nests that had advanced to incubation, and previously hatched nests for each day of the nesting season. The MINBPOP was then computed for each day of the nesting season and then we used the maximum for each study area and year. Shaffer and others (2013) simulated MINBPOP and associated BPOP values for conditions in each of the two study areas to determine the study-area-specific detection ratio (MINBPOP/BPOP) necessary to compute the BPOP estimate. See Shaffer and others (2013) for a more detailed explanation including model assumptions.

The BPOP can be calculated as the MINBPOP of the study area divided by the estimated detection ratio for that study area based on the level of nest success observed in that study area in the given year; this assumes daily nest detection rates are approximately 0.5 and nest visits occur semi-weekly (Shaffer and others, 2013). We used previously published estimates of BPOP for pre-flood years on GRR and SAK (Shaffer and others, 2013) and used the regression presented in figure 30 of Shaffer and others (2013) to extrapolate the BPOP for GRR and SAK in post-flood years using study-area-specific estimates of annual nest success (fig. 2).

\section{Results}

\section{Nest Survival}

We included 810 piping plover nests and 219 least tern nests initiated during pre-flood years (2006-9) in our analysis of nest survival (table 6). During post-flood years (2012-14), an additional 770 piping plover nests and 241 least tern nests were included in our nest survival analysis (table 6). An additional 68 least tern nests were tracked and fated on Lake Sakakawea during this time period (2006-14) but were not included in our nest survival analysis due to low annual sample sizes. On average, plover nests were discovered at a mean age of 5.5 days (plus or minus $[ \pm] 5.0$ days SD) and tern nests were found at a mean age of 3.6 days ( \pm 3.8 days SD) (table 3). The mean initiation date for plover nests was May 30 $( \pm 15$ day SD) and for tern nests was June 16 ( \pm 11.4 day SD) (table 3). 
Garrison River Reach, Gavins Point River Reach, and Lake Sakakawea
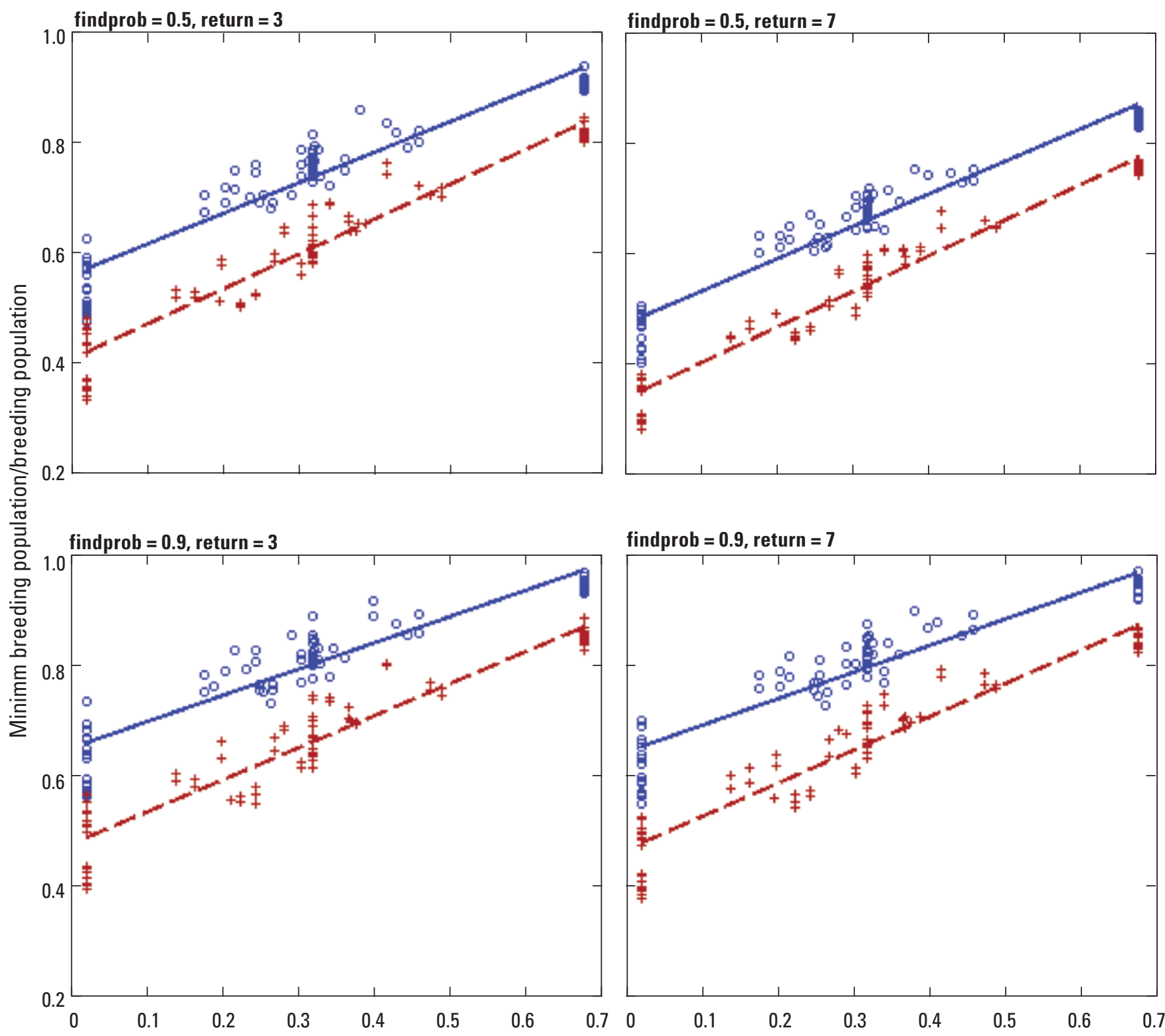

Nest success

\section{EXPLANATION}

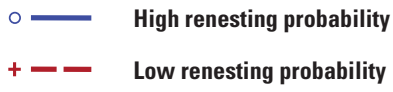

findprob Daily nest detection probability

return Return interval, in days

Figure 2. Minimum breeding population (MINBPOP) regressions used to extrapolate MINBPOP/breeding population (BPOP) values for estimating BPOP for least terns and piping plovers nesting on Lake Sakakawea and the Garrison Reach during 2012-14. Figure and legend from Shaffer and others (2013). 
Table 6. Sample of piping plover and least tern nests found and followed for the purpose of nest survival analysis by U.S. Geological Survey crews along the Garrison Reach and Lake Sakakawea.

[Pre-flood refers to years prior to the 2011 Missouri River flood; Post-flood refers to years following the 2011 Missouri River flood; GRR, Garrison Reach; --, data were not collected in a given year; SAK, Lake Sakakawea]

\begin{tabular}{|c|c|c|c|c|c|c|c|c|c|}
\hline \multirow{2}{*}{ Species } & \multirow{2}{*}{ Study area } & \multicolumn{4}{|c|}{ Pre-flood } & \multicolumn{3}{|c|}{ Post-flood } & \multirow{2}{*}{ Total } \\
\hline & & 2006 & 2007 & 2008 & 2009 & 2012 & 2013 & 2014 & \\
\hline \multirow[t]{2}{*}{ Piping plover } & GRR & 235 & 201 & -- & -- & 57 & 138 & 225 & 856 \\
\hline & SAK & 57 & 109 & 93 & 115 & 90 & 122 & 138 & 724 \\
\hline \multirow[t]{2}{*}{ Least tern } & GRR & 114 & 105 & -- & -- & 61 & 75 & 105 & 460 \\
\hline & SAK $^{1}$ & -- & 9 & 17 & 6 & 8 & 14 & 14 & 68 \\
\hline
\end{tabular}

${ }^{1}$ Although least tern nests on Lake Sakakawea were found and followed in 6 of the years, we did not include these nests in our nest survival analysis due to small annual sample sizes.

Piping plover nest survival varied by date and nest age as well as study area. Nest survival was lower on Lake Sakakawea than on the Garrison Reach in all years. Daily nest survival (DSR) in both study areas was associated with date but not in the same manner. The DSR on the Garrison Reach increased as the season progressed ( $\left.\hat{\beta}_{\text {PIPL-GRR-sdate }}=0.017 \pm 0.004 \mathrm{SE}\right)$, whereas the DSR of nests initiated on Lake Sakakawea decreased as the season progressed ( $\left.\hat{\beta}_{\text {PIPL-SAK-sdate }}=-0.024 \pm 0.004 \mathrm{SE}\right)$ (table 7, model 1). On the Garrison Reach, DSR increased with nest age $\left(\hat{\beta}_{\text {PIPL-GRR-sage }}=0.031 \pm 0.007 \mathrm{SE}\right)$ but we observed no such relation for nests initiated on Lake Sakakawea.

After controlling for the influence of study area, seasonal date, and nest age, we found strong support for annual variation in piping plover nest survival for both study areas (figs. 3 and 4; table 7, model 1). We additionally found weak support for an increase in cumulative nest survival in both study areas in post-flood years relative to pre-flood years (table 7, model 3 compared to model 11). However, examination of the individual annual estimates of cumulative nest survival to 35 days indicates that this effect was largely driven by high nest survival for both study areas during 2012 (figs. 3 and 4). We derived these estimates by assuming "sdate" was equal to the mean nest initiation date (May 30) and the associated "sage" was equal to 1 . For both study areas, we generated annual estimates using model $S$ (studyarea*year + sdate*studyarea + sage*studyarea) (Garrison Reach: $S_{\text {cumulative }} \pm$ SE: $S_{2006}=$ $0.245 \pm 0.019, S_{2007}=0.515 \pm 0.022, S_{2012}=0.729 \pm 0.023$, $S_{2013}=0.465 \pm 0.025, S_{2014}=0.458 \pm 0.022$; Lake Sakakawea: $S_{\text {cumulative }} \pm$ SE: $S_{2006}=0.126 \pm 0.019, S_{2007}=0.155 \pm 0.019, S_{2008}$ $=0.226 \pm 0.022, S_{2009}=0.002 \pm 0.001, S_{2012}=0.554 \pm 0.027$, $S_{2013}=0.203 \pm 0.021, S_{2014}=0.063 \pm 0.010$; table 7, model 1), (figs. 3 and 4). We estimated cumulative nest survival during the pre-flood (2006-7 for the Garrison Reach and 2006-9 for Lake Sakakawea) and post-flood (2012-14) periods using model $S$ (flood*studyarea + sdate*studyarea + sage*studyarea) (table 7, model 10). The estimates (Garrison Reach: $S_{\text {cumulative }}$ \pm SE: $S_{\text {prefflood }}=0.366 \pm 0.020, S_{\text {post-flood }}=0.499 \pm 0.020$; Lake Sakakawea: $S_{\text {cumulative }} \pm$ SE: $S_{\text {pre-flood }}=0.112 \pm 0.012, S_{\text {post-flood }}=$ $0.208 \pm 0.017$ ) are plotted in figures 3 and 4.

There was strong support for annual trends in the influence of nest age on piping plover DSR on the Garrison Reach during pre-flood years in our post-hoc analysis. We estimated daily nest survival rates for both study areas using the top-supported model from the first round of modelselection, model $S$ (sdate*studyarea + sage*studyarea), and annual estimates using post-hoc model $S$ (studyarea*year + sdate*studyarea*year + sage*studyarea) with the "sdate" value associated with "sage" $=1$ solved for May 30. Daily survival rate increased with nest age on the Garrison Reach during both pre-flood years, and the age-related trends were strongly supported for both $2006(\hat{\beta}=0.029 \pm 0.013 \mathrm{SE})$ and 2007 ( $\hat{\beta}=0.072 \pm 0.017$ SE) (fig. 5); date-related trends were also strongly supported for Garrison piping plovers for $2006(\hat{\beta}=0.031 \pm 0.006)$ and $2007(\hat{\beta}=0.017 \pm 0.007)$ (fig. 6). However, there was no support for annual effects of age (fig. 5) or seasonal date (fig. 6) during 2012-14. On Lake Sakakawea, age-related trends were only supported during 2006 ( $\hat{\beta}=-0.059 \pm 0.027$; fig. 7). Seasonal date-related trends indicating declining nest survival with increasing seasonal date were supported for 2007 ( $\hat{\beta}=-0.018 \pm 0.007), 2008$ $(\hat{\beta}=-0.041 \pm 0.009), 2009(\hat{\beta}=-0.016 \pm 0.009)$, and 2013 ( $\hat{\beta}=-0.055 \pm 0.009)$ (fig. 8).

Least tern nest survival was explained by date and nest age (table 8 , model 1$)$. The DSR for tern nests initiated on the Garrison Reach increased with nest age $\left(\hat{\beta}_{\text {LETE-GRR-sage }}=\right.$ $0.553 \pm 0.225 \mathrm{SE})$. Although there was no significant relation between seasonal date and nest survival, we did find support for an interaction between nest age and seasonal date $\left(\hat{\beta}_{\text {LETE-GRR-sage }} *\right.$ sdate $\left.=-0.003 \pm 0.001 \mathrm{SE}\right)$; as the nesting season progressed, the higher survival associated with older nests attenuated. 
Table 7. Ranked set of logistic-exposure models used to estimate daily piping plover nest survival following the second stage of model selection: examination of the effect of the 2011 Missouri River flood. Models ranked according to lowest Akaike's Information Criterion (AICc) value corrected for small sample size.

[No., the model rank; Pred., the prediction the model was intended to represent; $\triangle \mathrm{AICc}$, the change in AICc relative to the top-ranked model; $k$, the number of parameters in the model; $w_{i}$, the model weight; *, a multiplicative relationship; + , an additive relationship; $<$, less than]

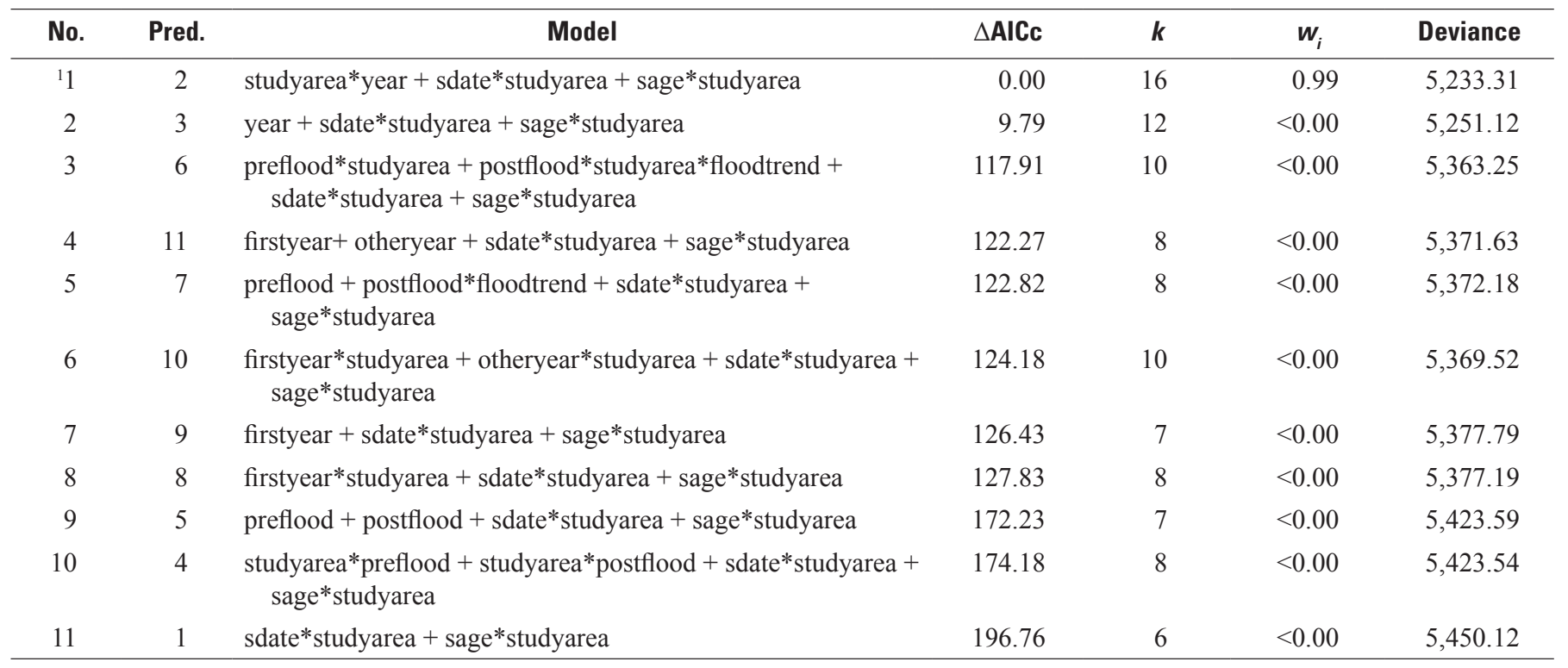

${ }^{1} \mathrm{AICc}$ of top-ranked model was $5,265.37$.

We generated annual nest survival estimates for least terns on the Garrison Reach using model $S$ (year + sdate*sage) (table 8, model 1) and cumulative survival with 95-percent confidence intervals using the Delta method. For these and all subsequent least tern nest survival estimates, we derived these estimates by assuming "sdate" was equal to the mean nest initiation date (June 16) and the associated "sage" was equal to 1 . After controlling for the influence of study area, date, and nest age, we found support for annual variation in least tern nest survival (fig. 9; $S_{\text {cumulative }} \pm$ SE: $S_{2006}=0.607$ $\pm 0.031, S_{2007}=0.803 \pm 0.020, S_{2012}=0.748 \pm 0.027, S_{2013}=$ $\left.0.818 \pm 0.021, S_{2014}=0.729 \pm 0.025\right)$; however, we found no support to indicate this annual variation was related to any of our predicted effects of the flood (table 8, model 2 compared to models 3-6). Estimates of cumulative nest survival during the pre-flood (2006-7) and post-flood (2012-14) period were generated using model $S$ (flood + sdate*sage) (table 8, model 4;
$S_{\text {cumulative }} \pm$ SE: $S_{\text {pre-flood }}=0.708 \pm 0.023, S_{\text {post-flood }}=0.760 \pm$ 0.020 ). Examination of the individual annual estimates of cumulative nest survival to 21 days indicates that although cumulative nest survival was higher during 2012-14 (postflood) than in 2006 (pre-flood), it was similar to nest survival during 2007 (pre-flood) (fig. 10).

We generated overall trend estimates of least tern daily nest survival by age using the top-supported model from the first round of model-selection, model $S$ (sage + sdate + sage*sdate), and annual estimates using post-hoc model $S$ (year + sdate + sage*year + sdate*sage) with the "sdate" value associated with "sage" $=1$ solved for June 16. Age-related trends were strongly supported for 2006 ( $\hat{\beta}=0.647 \pm 0.236 \mathrm{SE})$, $2007(\hat{\beta}=0.680 \pm 0.245 \mathrm{SE}), 2012(\hat{\beta}=0.602 \pm 0.245 \mathrm{SE})$, $2013(\hat{\beta}=0.501 \pm 0.245 \mathrm{SE})$, and $2014(\hat{\beta}=0.704 \pm 0.249$ SE) (fig. 10). 


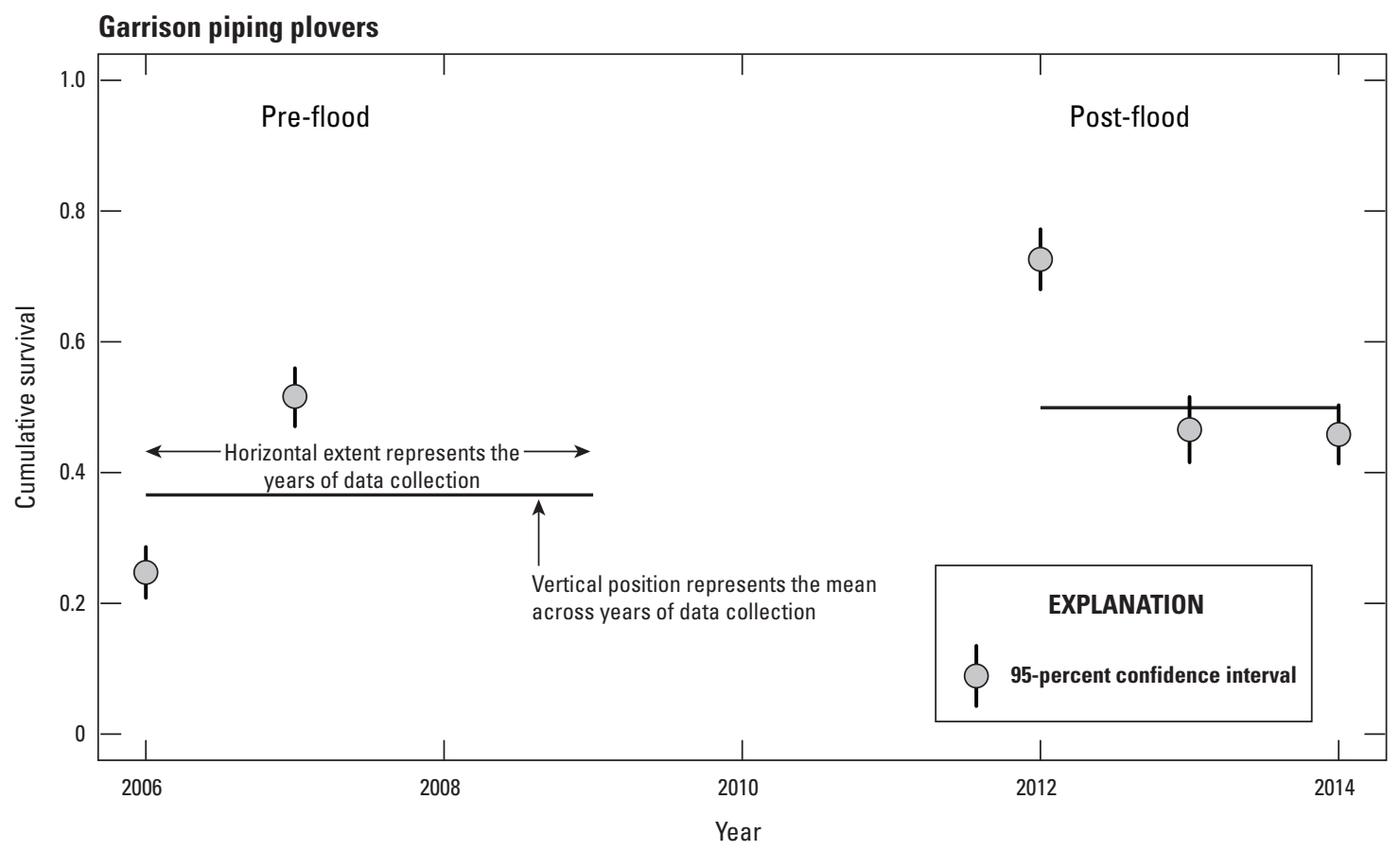

Figure 3. Cumulative estimates of piping plover nest survival (35 days) along the Garrison Reach by year and for the pre-flood and post-flood periods. Pre- and post-flood period indicated with horizontal line.

Sakakawea piping plovers

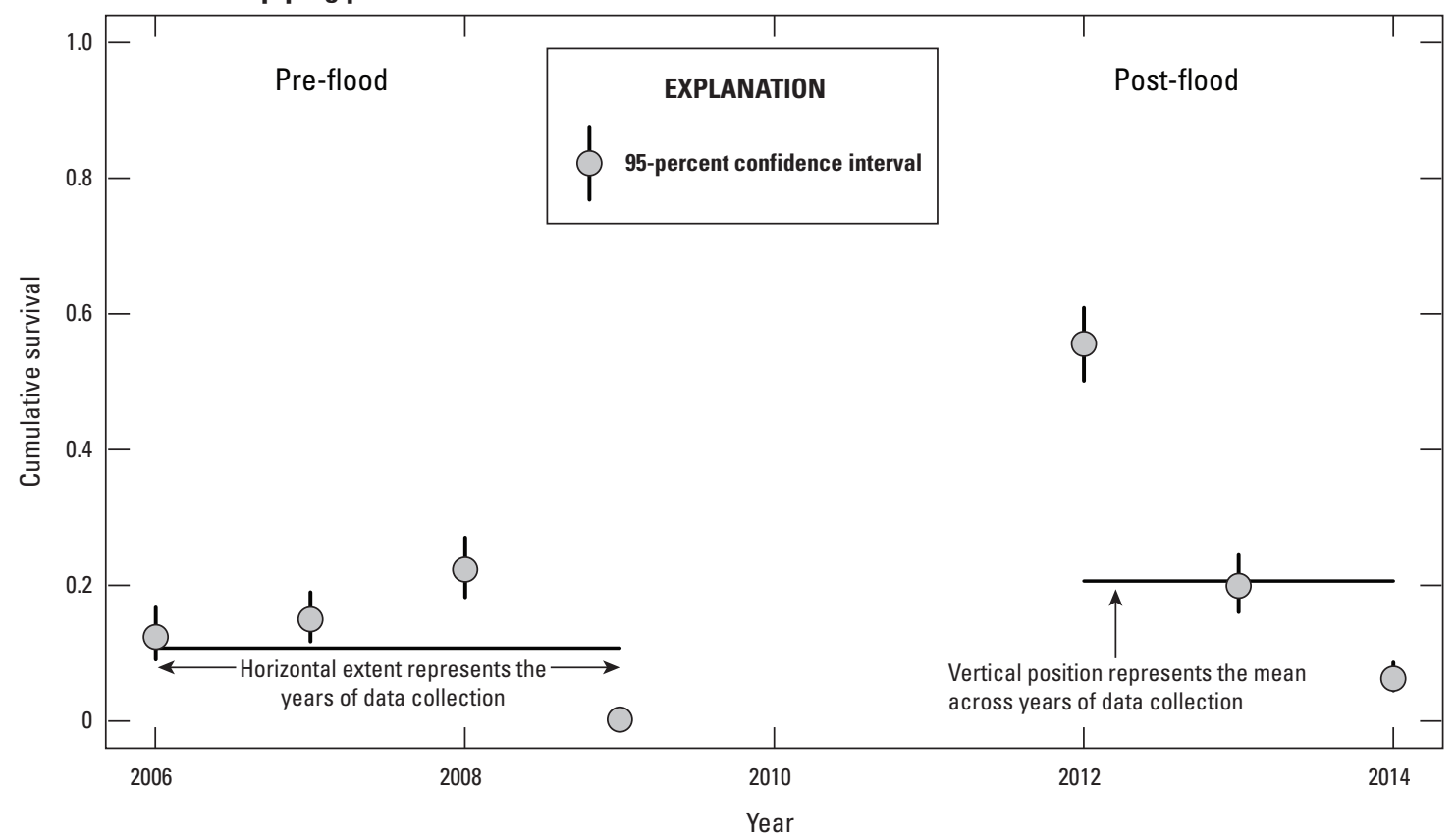

Figure 4. Cumulative estimates of piping plover nest survival (35 days) on Lake Sakakawea by year and for the pre-flood and post-flood periods. Pre- and post-flood period indicated with horizontal line. 


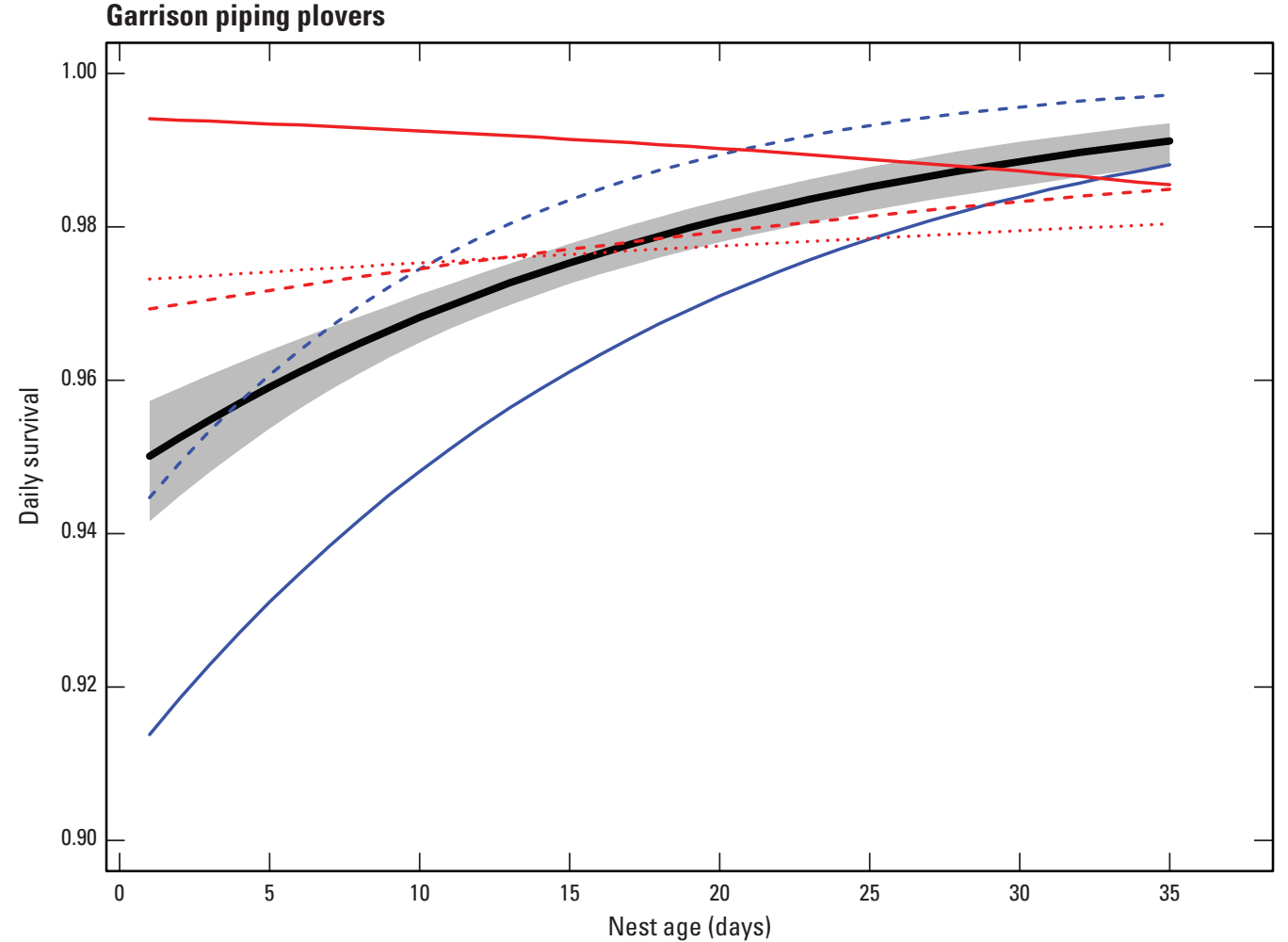

Garrison piping plovers

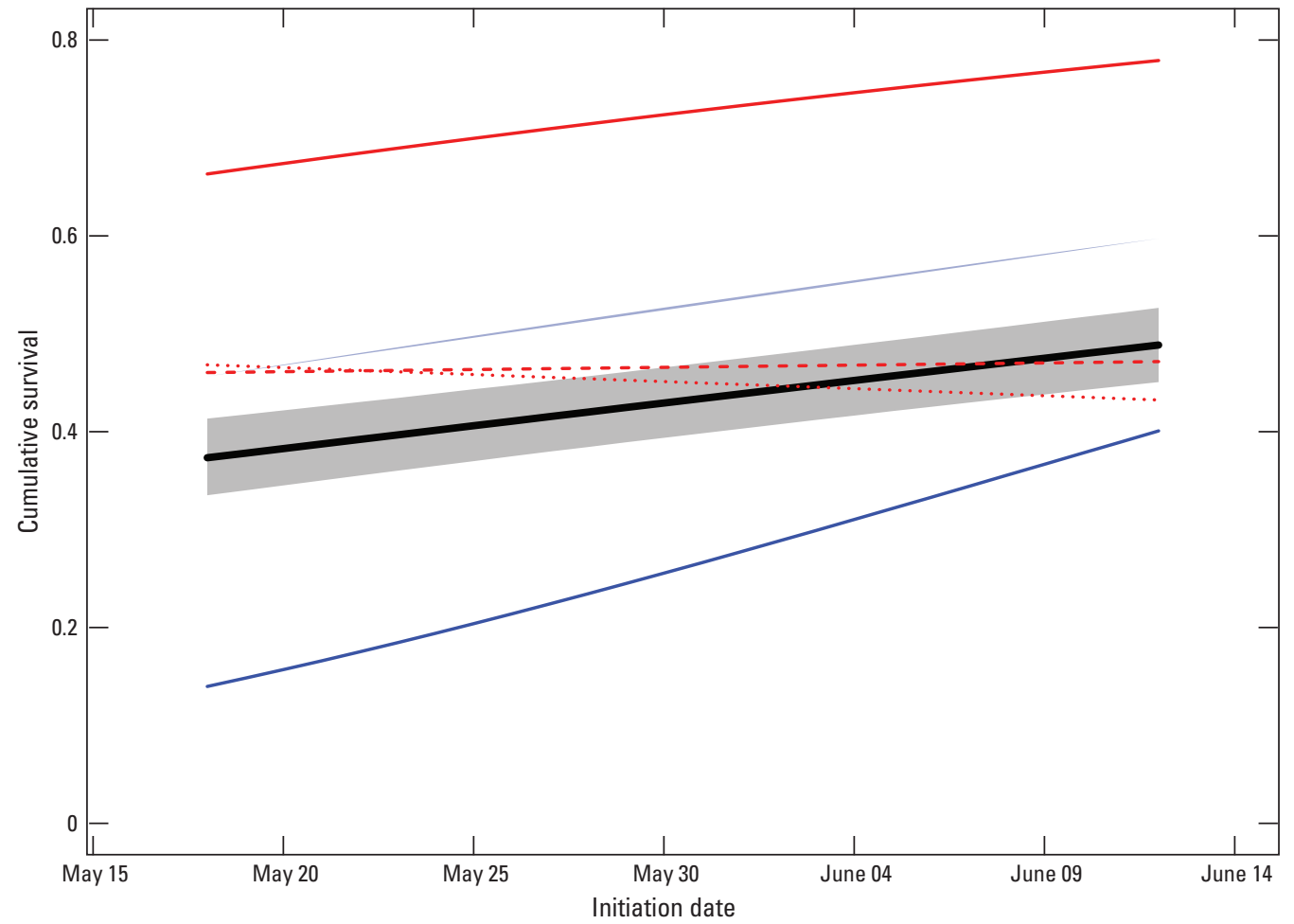

\section{EXPLANATION}

2006

- - - 2007

2012

- . - 2013

....... 2014

Overall trend of daily survival by age

95-percent confidence envelope

Figure 5. Daily survival estimates for piping plover nests along the Garrison Reach by nest age and year. The solid black line represents an overall trend of daily nest survival by age, and the solid gray shading represents a 95-percent confidence envelope.

Figure 6. Cumulative estimates of piping plover nest survival (35 days) along the Garrison Reach by nest initiation date and year. The solid black line represents an overall trend of daily nest survival by nest initiation date, and the solid gray shading represents a 95-percent confidence envelope. 

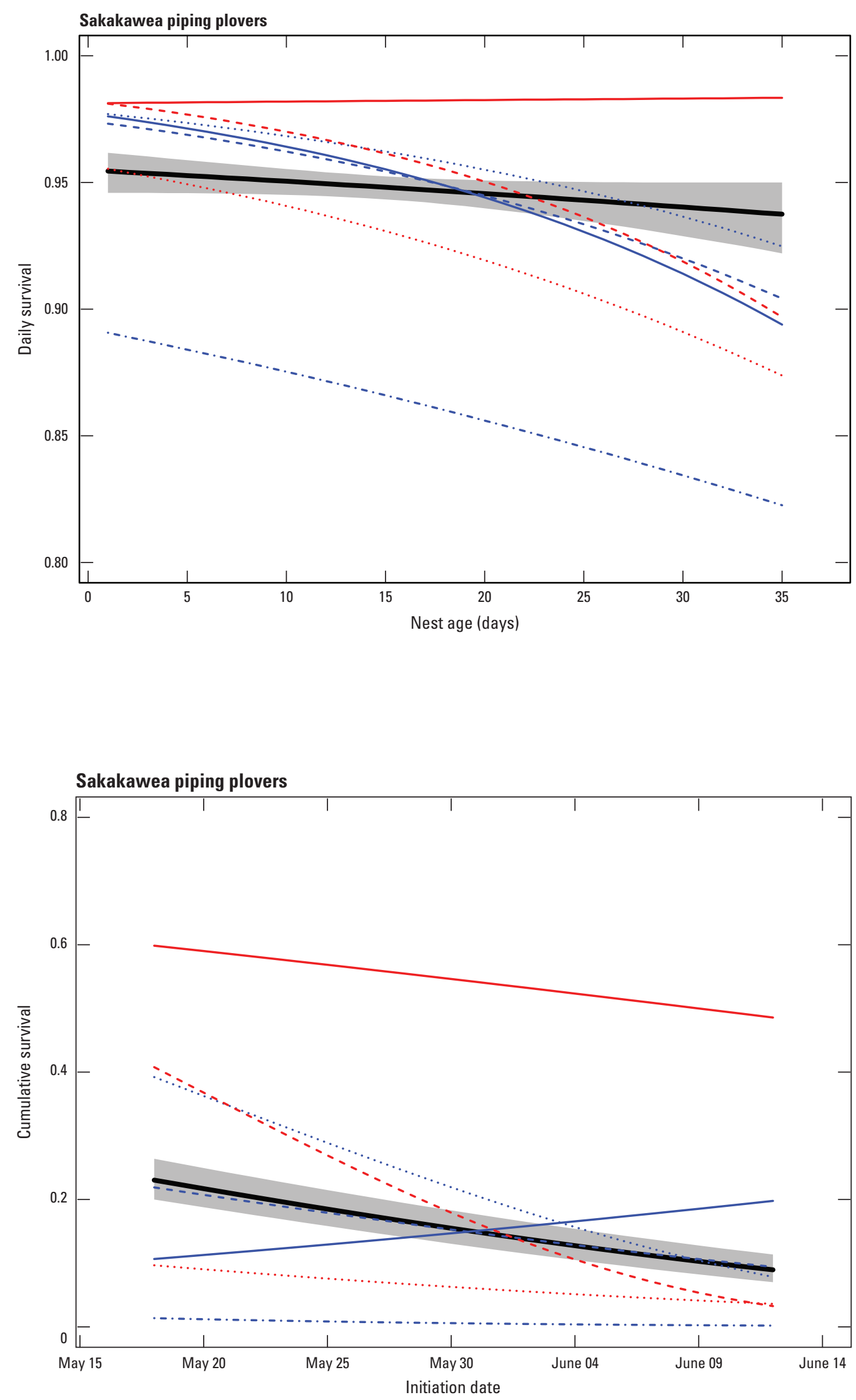

\author{
EXPLANATION \\ $-2006$ \\ $---2007$ \\ ….... 2008 \\ -....- 2009 \\ 2012 \\ $----2013$ \\ ….... 2014 \\ Overall trend of daily \\ survival by age \\ 95-percent confidence \\ envelope
}

Figure 7. Daily survival estimates for piping plover nests on Lake Sakakawea by nest age and year. The solid black line represents an overall trend of daily nest survival by age, and the solid gray shading represents a 95-percent confidence envelope.
Figure 8. Cumulative estimates of piping plover nest survival (35 days) on Lake Sakakawea by nest initiation date and year. The solid black line represents an overall trend of daily nest survival by nest initiation date, and the solid gray shading represents a 95-percent confidence envelope. 
Table 8. Ranked set of logistic exposure models used to estimate daily least tern nest survival following the second stage of model selection: examination of the effect of the 2011 Missouri River flood. Models ranked according to lowest Akaike's Information Criterion (AICc) value corrected for small sample size.

[No., the model rank; Pred., the prediction the model was intended to represent; $\triangle \mathrm{AICc}$, the change in AICc relative to the top-ranked model; $\mathrm{k}$, the number of parameters in the model; $\mathrm{w}_{i}$, the model weight; *, a multiplicative relationship; +, an additive relationship]

\begin{tabular}{ccccccc}
\hline No. & Pred. & \multicolumn{1}{c}{ Model } & $\Delta$ AICc & $\boldsymbol{k}$ & $\boldsymbol{w}_{\boldsymbol{i}}$ & Deviance \\
\hline${ }^{1} 1$ & 3 & year+ sdate*sage & 0.00 & 8 & 0.62 & 772.65 \\
2 & 1 & sdate*sage & 3.44 & 4 & 0.11 & 784.13 \\
3 & 9 & firstyear + sdate*sage & 3.80 & 4 & 0.09 & 784.49 \\
4 & 5 & preflood + postflood + sdate*sage & 4.17 & 5 & 0.08 & 782.86 \\
5 & 11 & firstyear + otheryear + sdate*sage & 4.58 & 5 & 0.07 & 783.27 \\
6 & 7 & preflood + postflood*floodtrend + sdate*sage & 5.96 & 6 & 0.03 & 782.64 \\
\hline
\end{tabular}

${ }^{1} \mathrm{AICc}$ of top-ranked model was 788.72 .

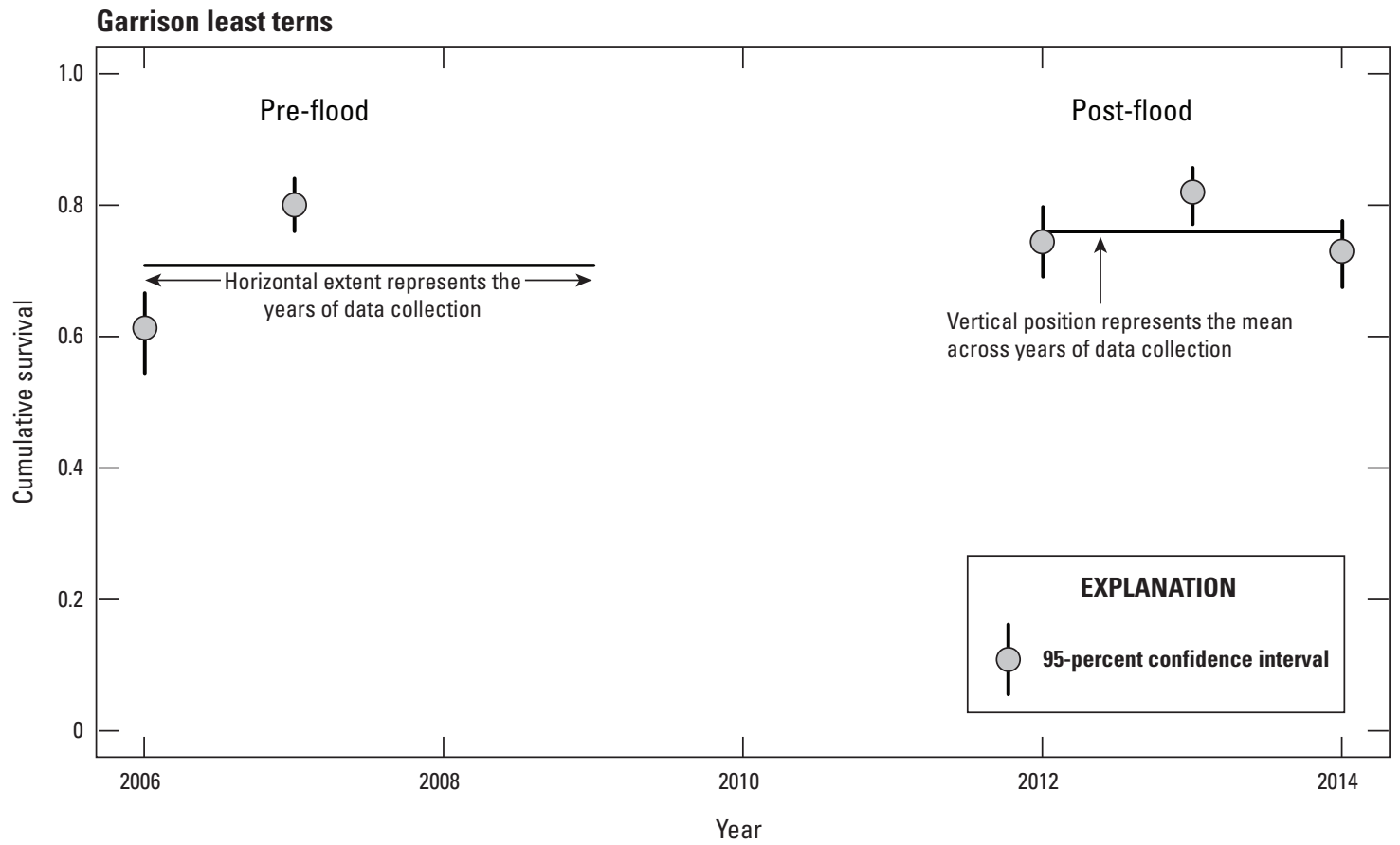

Figure 9. Cumulative estimates of least tern nest survival (21 days) along the Garrison Reach by year and for the pre-flood and post-flood periods. Pre- and post-flood period indicated with horizontal line. 


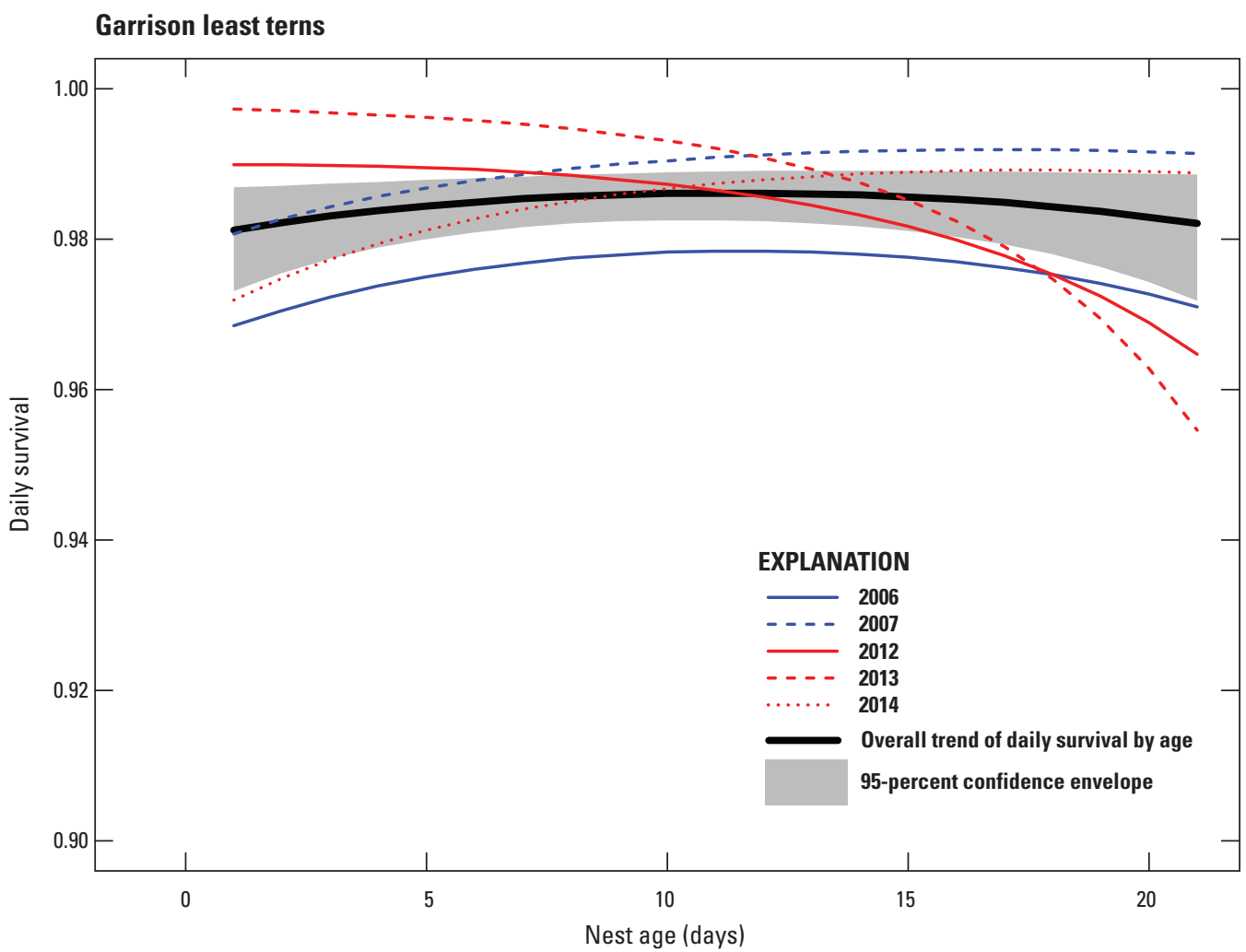

Figure 10. Daily survival estimates for least tern nests along the Garrison Reach by nest age and year.

\section{Chick Survival}

We included 586 uniquely marked piping plover chicks and 338 uniquely marked least tern chicks resighted/recaptured during pre-flood years (2006-9) in our analysis of chick survival to fledging (table 9). During post-flood years (2012-14), we included an additional 828 piping plover chicks and 346 least tern chicks in our analysis of chick survival to fledging (table 9). An additional 60 least tern chicks were uniquely marked and resighted/recaptured on Lake Sakakawea during this time period (2006-14), but were not included in our chick survival analysis due to low annual sample sizes. On average, plover chicks were banded at a mean age of 2.5 days ( \pm 3.5 days SD) and tern chicks were banded at a mean age of 1.8 days ( \pm 2.7 days $\mathrm{SD}$ ) (table 5 ). The mean hatch date for plover chicks was June 28 ( \pm 14.8 day SD) and for tern chicks was July 4 ( \pm 8.7 day SD) (table 5).

Daily piping plover chick detection was determined by whether or not a chick had fledged, the study area where the chick hatched, and the year of the study. Detection probabilities were higher for pre-fledge chicks and were generally higher on Lake Sakakawea than on the Garrison Reach (table 10).

Piping plover chick survival was correlated with chick age but not with date. The DSR increased with chick age for plover chicks hatched on the Garrison Reach $\left(\hat{\beta}_{\text {PIPL-GRR-age }}=0.042 \pm 0.021 \mathrm{SE}\right)$ and on Lake Sakakawea $\left(\hat{\beta}_{\text {PIPL-SAK-age }}=0.037 \pm 0.001 \mathrm{SE}\right)$. After controlling for the influence of chick age on survival, we found support for flood-related variation in piping plover chick survival (table 11, model 1). We additionally found weak support for an increase in cumulative chick survival in both study areas in post-flood years relative to pre-flood years (table 11, model 2 compared to model 11). We generated annual estimates using model $[\varphi($ postF*studyarea + studyarea* $\mathrm{d} 1$ toF + studyarea*year*d1 toF + studyarea*d1 toF*age), $p\left(\right.$ postF*year*studyarea $+\mathrm{d} 2$ toF* $^{*}$ year*studyarea)] (table 11, model 8), and cumulative survival and associated 95-percent confidence intervals (vertical bars) using the Delta method. Examination of the individual annual estimates of cumulative chick survival to fledging (25 days) indicates the two study areas followed separate patterns. In the first year following the flood (2012), chick survival on the Garrison Reach was similar to that estimated for 2007, but it progressively increased through $2014\left(\varphi_{\text {cumulative }} \pm\right.$ SE: $\varphi_{2007}=0.398 \pm 0.048, \varphi_{2012}=$ $0.435 \pm 0.079, \varphi_{2013}=0.519 \pm 0.070, \varphi_{2014}=0.714 \pm 0.072$ ) (fig. 11). Chick survival steadily increased following the flood (fig. 11). On Lake Sakakawea, chick survival was demonstrably higher in 2012 than any of the other years $\left(\varphi_{\text {cumulative }} \pm \mathrm{SE}\right.$ : $\varphi_{2007}=0.318 \pm 0.081, \varphi_{2008}=0.177 \pm 0.060, \varphi_{2012}=0.594 \pm$ $0.109, \varphi_{2013}=0.442 \pm 0.097, \varphi_{2014}=0.4694 \pm 0.206$ ) (fig. 12). We do not present annual estimates for 2006 and 2009 on Lake Sakakawea because low sample sizes precluded accurate estimates of annual survival in these years. We did not find any strong support for annual trends in the effect of chick age or seasonal date on piping plover chick DSR in our post-hoc 
Table 9. Sample of piping plover and least tern chicks captured and banded by U.S. Geological Survey crews along the Garrison Reach and Lake Sakakawea.

[Pre-flood refers to years prior to the 2011 Missouri River flood; Post-flood refers to years following the 2011 Missouri River flood; GRR, Garrison Reach; --, data was not collected in a given year; SAK, Lake Sakakawea]

\begin{tabular}{|c|c|c|c|c|c|c|c|c|c|}
\hline \multirow{2}{*}{ Species } & \multirow{2}{*}{ Study area } & \multicolumn{4}{|c|}{ Pre-flood } & \multicolumn{3}{|c|}{ Post-flood } & \multirow{2}{*}{ Total } \\
\hline & & 2006 & 2007 & 2008 & 2009 & 2012 & 2013 & 2014 & \\
\hline \multirow[t]{2}{*}{ Piping plover } & GRR & -- & 355 & -- & -- & 141 & 201 & 232 & 929 \\
\hline & SAK & 12 & 98 & 123 & 8 & 142 & 93 & 19 & 485 \\
\hline \multirow[t]{2}{*}{ Least tern } & GRR & 171 & 167 & -- & -- & 109 & 105 & 132 & 684 \\
\hline & SAK $^{1}$ & -- & 9 & 15 & 6 & 10 & 17 & 5 & 60 \\
\hline
\end{tabular}

${ }^{1}$ Although least tern chicks on Lake Sakakawea were captured and banded in 6 of the years, we did not include these nests in our analysis of chick survival due to small annual sample sizes.

Table 10. Daily detection probability estimates (p) and associated 95-percent confidence intervals for uniquely marked pre-fledge (less than 25 days) and fledged (25+ days) piping plover chicks resighted/recaptured on the Garrison Reach and Lake Sakakawea for all years of the study. All estimates were generated using model $[\varphi$ (postF + studyarea*d1toF* preflood + studyarea*d1toF*firstyear + studyarea*d1toF*otheryear + studyarea*d1toF*age), $p\left(\right.$ postF*year*studyarea $+\mathrm{d} 2$ toF $^{*}$ year*studyarea)], (tables 10 and 11 , model 1 ).

[GRR, Garrison Reach; SAK, Lake Sakakawea]

\begin{tabular}{|c|c|c|c|c|c|}
\hline Study area & Stage & Year & Estimate & 95\% LCL & $95 \%$ UCL \\
\hline \multirow[t]{8}{*}{ GRR } & Pre-fledge & 2007 & 0.522 & 0.481 & 0.562 \\
\hline & & 2012 & 0.443 & 0.386 & 0.502 \\
\hline & & 2013 & 0.389 & 0.348 & 0.431 \\
\hline & & 2014 & 0.319 & 0.281 & 0.360 \\
\hline & Fledged & 2007 & 0.242 & 0.176 & 0.322 \\
\hline & & 2012 & 0.275 & 0.182 & 0.392 \\
\hline & & 2013 & 0.248 & 0.168 & 0.349 \\
\hline & & 2014 & 0.206 & 0.146 & 0.283 \\
\hline \multirow[t]{12}{*}{ SAK } & Pre-fledge & 2006 & 0.660 & 0.592 & 0.721 \\
\hline & & 2007 & 0.737 & 0.657 & 0.804 \\
\hline & & 2008 & 0.378 & 0.308 & 0.452 \\
\hline & & 2009 & 0.615 & 0.531 & 0.693 \\
\hline & & 2012 & 0.675 & 0.492 & 0.817 \\
\hline & & 2013 & 0.565 & 0.481 & 0.645 \\
\hline & & 2014 & 0.611 & 0.515 & 0.699 \\
\hline & Fledged & 2007 & 0.321 & 0.192 & 0.485 \\
\hline & & 2008 & 0.352 & 0.201 & 0.541 \\
\hline & & 2012 & 0.111 & 0.062 & 0.191 \\
\hline & & 2013 & 0.189 & 0.101 & 0.326 \\
\hline & & 2014 & 0.231 & 0.076 & 0.522 \\
\hline
\end{tabular}


analysis. Estimates of cumulative chick survival during the pre-flood (2007-8) and post-flood (2012-14) period were generated using model $\left[\varphi\left(_{\text {postF }}+\right.\right.$ studyarea*preflood*d1toF + studyarea*postflood*d1 toF + studyarea*d1 toF*age)] (table 11, model 4$)$ for both the Garrison Reach $\left(\varphi_{\text {cumulative }} \pm \mathrm{SE}: \varphi_{\text {prefflood }}=\right.$ $\left.0.398 \pm 0.048, \varphi_{\text {post-flood }}=0.561 \pm 0.043\right)$ and Lake Sakakawea $\left(\varphi_{\text {cumulative }} \pm \mathrm{SE}: \varphi_{\text {pre-flood }}=0.253 \pm 0.051, \varphi_{\text {post-flood }}=0.508 \pm\right.$ $0.068)$. All estimates were generated assuming "date" associated with "age" = 1 equal to the mean hatch date (June 28).

Daily least tern chick detection was determined by whether or not a chick had fledged, the year of the study, and the age of the chick. Detection probabilities were generally higher for pre-fledge chicks and declined with chick age (table 12).

Least tern chick survival was explained by chick age but not by seasonal date. Daily survival of tern chicks on the Garrison Reach increased with chick age $\left(\hat{\beta}_{\text {LETE-GRR-age }}=\right.$ $0.041 \pm 0.001 \mathrm{SE})$. After controlling for chick age, we found strong support for annual variation in least tern chick survival (fig. 1; fig. 13, model 1). We generated annual estimates using model $[\varphi($ postF $+\mathrm{d} 1$ toF + year*d1toF $+\mathrm{d} 1$ toF*age $)$, $p($ postF*year*age + age*year*d2toF)] (fig. 13, model 1) and cumulative survival and associated 95 -percent confidence intervals using the Delta method. Specifically, the results indicate chick survival was markedly higher in the year immediately following the flood than in any other year (fig. 13, model 2 compared to models $3-6)\left(\varphi_{\text {cumulative }} \pm \mathrm{SE}: \varphi_{2006}=\right.$ $0.688 \pm 0.053, \varphi_{2007}=0.446 \pm 0.055, \varphi_{2012}=0.931 \pm 0.053$, $\left.\varphi_{2013}=0.513 \pm 0.078, \varphi_{2014}=0.461 \pm 0.113\right)$. We estimated cumulative chick survival during the pre-flood (2006-7) and post-flood (2012-14) period using model $[\varphi($ postF + d1 toF*preflood + d1 toF*postflood + d1 toF*floodtrend + d1 toF*age), $p$ (postF*year*age + age*year*d2toF)] and found that post-flood survival was higher than pre-flood survival) $\left(\varphi_{\text {cumulative }} \pm \mathrm{SE}: \varphi_{\text {pre-flood }}=0.570 \pm 0.040, \varphi_{\text {post-flood }}=0.752 \pm\right.$ $0.063)$. All estimates were generated assuming "date" associated with "age" = 1 equal to the mean hatch date (July 4). We did not find any strong support for annual trends in the effect of chick age and date on least tern chick DSR in our post-hoc analysis.

Garrison piping plovers

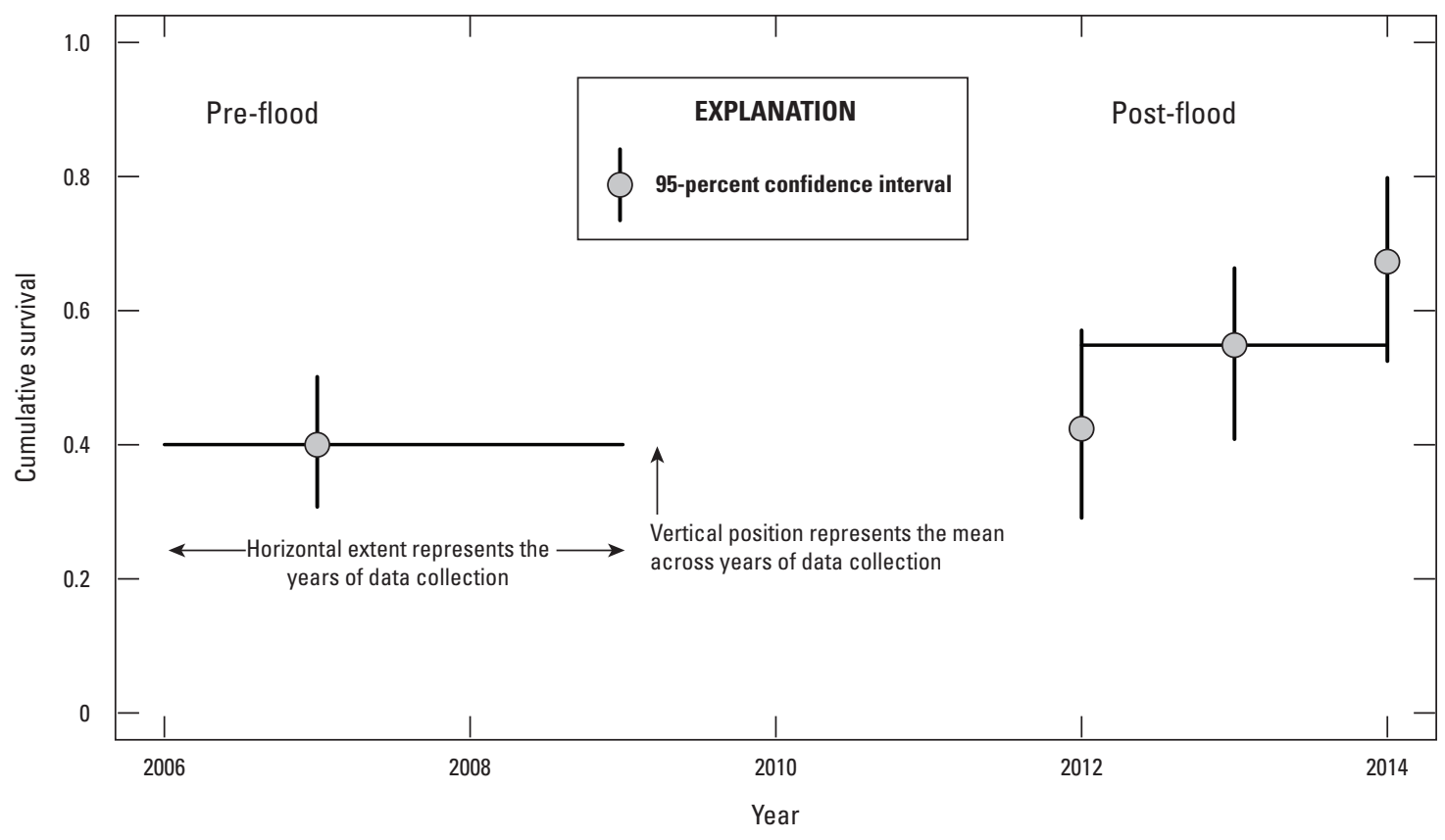

Figure 11. Cumulative estimates of piping plover chick survival to fledging ( 25 days) along the Garrison Reach by year and for the pre-flood and post-flood periods. Pre- and post-flood period indicated with horizontal line. 
Sakakawea piping plovers

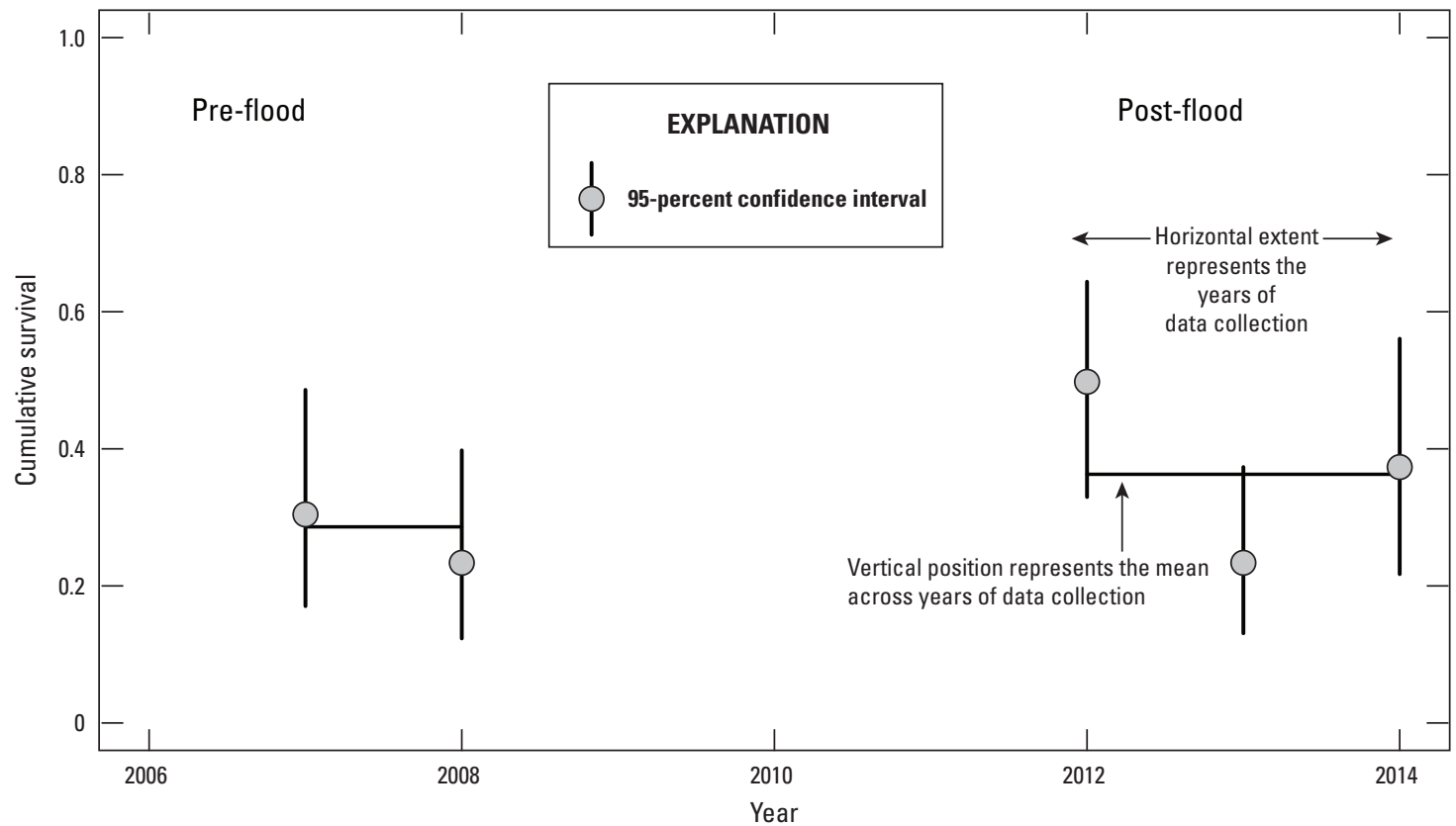

Figure 12. Cumulative estimates of piping plover chick survival to fledging (25 days) on Lake Sakakawea by year and for the pre-flood and post-flood periods. Pre- and post-flood period indicated with horizontal line.

Table 11. Ranked set of Cormack-Jolly-Seber models used to estimate daily piping plover chick survival following the third stage of model selection: examination of the effect of the 2011 Missouri River flood. Models ranked according to lowest Quasi-Akaike's Information Criterion (QAICc) value corrected for small sample size and overdispersion ( $\hat{c}=2.91)$. For all models, detection $(p)$ was parameterized as $p\left(\right.$ postF* $^{*}$ ear*studyarea $+\mathrm{d} 2$ toF $^{*}$ year*studyarea).

[No., the model rank; Pred., the prediction the model was intended to represent; $\varphi$, survival; $\triangle \mathrm{QAICc}$, the change in QAICc relative to the top-ranked model; $k$, the number of parameters in the model; $w_{i}$, the model weight; QDeviance, quasi-deviance; *, a multiplicative relationship; +, an additive relationship]

\begin{tabular}{|c|c|c|c|c|c|c|}
\hline No. & Pred. & Model $(\varphi)$ & $\triangle Q A I C c$ & $\boldsymbol{k}$ & $w_{i}$ & QDeviance \\
\hline${ }^{1} 1$ & 7 & postF $+\mathrm{d} 1$ toF*preflood $+\mathrm{d} 1$ toF*postflood $+\mathrm{d} 1$ toF*floodtrend + studyarea*d1 toF*age & 0.00 & 28 & 0.33 & $2,724.19$ \\
\hline 2 & 6 & $\begin{array}{l}\text { postF + studyarea*d } 1 \text { toF*preflood + studyarea*d1 toF*postflood + studyarea*d1 toF*floodtrend } \\
+ \text { studyarea*d } 1 \text { toF*age }\end{array}$ & 0.35 & 31 & 0.28 & $2,718.48$ \\
\hline 3 & 11 & postF $+\mathrm{d} 1$ toF* preflood $+\mathrm{d} 1$ toF*firstyear $+\mathrm{d} 1$ toF*otheryear + studyarea*d 1 toF*age & 2.02 & 28 & 0.12 & $2,726.22$ \\
\hline 4 & 5 & postF + studyarea $* \mathrm{~d} 1$ toF + preflood $* \mathrm{~d} 1$ toF + postflood $* \mathrm{~d} 1$ toF + studyarea $* \mathrm{~d} 1$ toF $*$ age & 2.34 & 28 & 0.11 & $2,726.53$ \\
\hline 5 & 19 & $\begin{array}{l}\text { postF }+ \text { studyarea*d } 1 \text { toF* preflood }+ \text { studyarea*d } 1 \text { toF*firstyear }+ \text { studyarea*d } 1 \text { toF*otheryear }+ \\
\text { studyarea*d } 1 \text { toF*age }\end{array}$ & 3.13 & 31 & 0.07 & $2,721.27$ \\
\hline 6 & 4 & $\begin{array}{l}\text { post } \mathrm{F}+\text { studyarea*d } 1 \text { toF }+ \text { studyarea*preflood*d1toF }+ \text { studyarea*postflood*d } 1 \text { toF }+ \\
\text { studyarea*d } 1 \text { toF*age }\end{array}$ & 3.66 & 29 & 0.05 & $2,725.83$ \\
\hline 7 & 3 & postF + studyarea*d 1 toF + year*d 1 toF + studyarea*d 1 toF*age & 4.10 & 33 & 0.04 & $2,718.19$ \\
\hline 8 & 2 & postF + studyarea*year*d 1 toF + studyarea*d1 toF*age & 6.64 & 36 & 0.01 & $2,714.66$ \\
\hline 9 & 8 & postF + studyarea*d 1 toF + studyarea*d 1 toF*firstyear + studyarea*d 1 toF*age & 11.81 & 29 & $<0.00$ & $2,733.99$ \\
\hline
\end{tabular}

${ }^{1}$ QAICc for top supported model is 5,983.47. 
Table 12. Daily detection probability estimates $(p)$ and associated 95-percent confidence intervals for uniquely marked pre-fledge (less than 18 days) and fledged (18+ days) least tern chicks resighted/recaptured on the Garrison Reach (GRR) for all years of the study. All estimates were generated by taking the geometric means of age-dependent estimates from model $\left[\varphi\left(\right.\right.$ post $F+d 1$ to $F+$ year* ${ }^{*} 1$ to $F+d 1$ to $F^{*}$ age $)$, p(postF* year*age + age ${ }^{*}$ year*d2toF)], (fig. 13, model 1$)$.

[LCL, lower confidence level; UCL, upper confidence level]

\begin{tabular}{ccccc}
\hline Stage & Year & Estimate & 95\% LCL & 95\% UCL \\
\hline Pre-fledge & 2006 & 0.272 & 0.234 & 0.313 \\
& 2007 & 0.366 & 0.309 & 0.426 \\
& 2012 & 0.195 & 0.163 & 0.231 \\
& 2013 & 0.188 & 0.146 & 0.240 \\
& 2014 & 0.134 & 0.094 & 0.189 \\
Fledged & 2006 & 0.181 & 0.146 & 0.222 \\
& 2007 & 0.132 & 0.096 & 0.179 \\
& 2012 & 0.144 & 0.109 & 0.186 \\
& 2013 & 0.079 & 0.047 & 0.127 \\
& 2014 & 0.036 & 0.018 & 0.070 \\
\hline
\end{tabular}

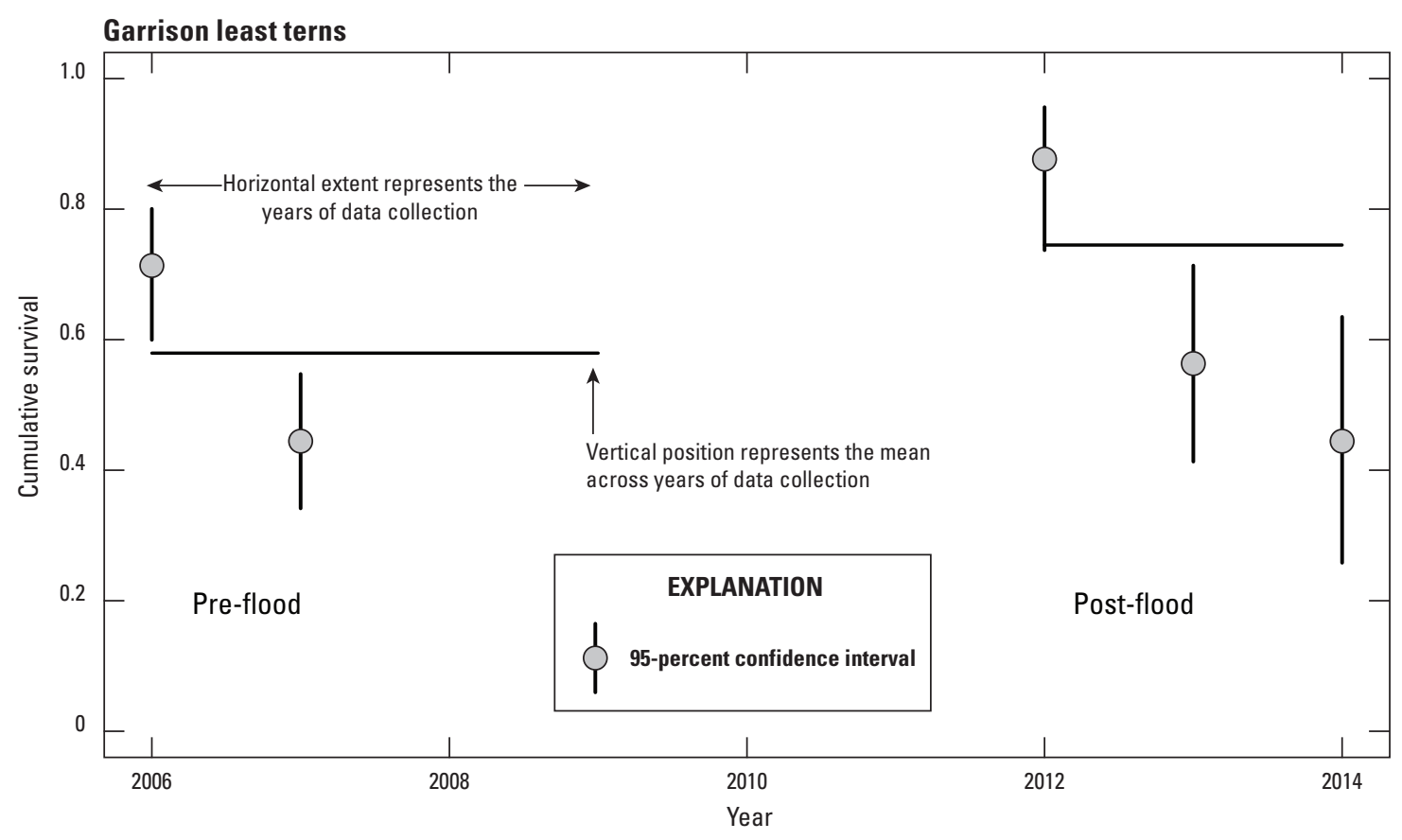

Figure 13. Cumulative estimates of least tern chick survival to fledging (18 days) along the Garrison Reach by year and for the pre-flood and post-flood periods. Pre- and post-flood period indicated with horizontal line.

\section{Adult Survival}

We included 441 uniquely marked piping plovers observed on the Garrison Reach and 392 plovers observed on Lake Sakakawea in our study-area-specific analysis of annual adult apparent survival and detection (table 14). Apparent survival of adult piping plovers was higher for individuals observed on the Garrison Reach $\left(\varphi_{\text {GRR }}=0.759 \pm 0.019 \mathrm{SE}\right)$ than for those observed on Lake Sakakawea $\left(\varphi_{\mathrm{SAK}}=0.658\right.$ $\pm 0.031 \mathrm{SE}$ ) (fig. 1). The annual probability of detecting a uniquely marked piping plover adult was higher on the Garrison Reach $\left(p_{\text {GRR }}=0.923 \pm 0.019 \mathrm{SE}\right)$ than on Lake Sakakawea $\left(\mathrm{p}_{S A K}=0.604 \pm 0.043 \mathrm{SE}\right)$.

We included 810 piping plovers in our analysis of adult survival for both study areas combined (table 14). The overall estimate of annual adult apparent survival across both study areas was generated using model [ $\varphi$ (constant), $p$ (constant)] and was $0.721 \pm 0.024 \mathrm{SE}$ (fig. 1). Adult apparent annual survival estimates and associated 95-percent confidence intervals by study area were generated using model $[\varphi$ (studyarea), $p$ (studyarea)], and reflected higher adult survival on the Garrison Reach than on Lake Sakakawea $\left(\varphi_{\text {GRR }}=0.759 \pm 0.019 \mathrm{SE}\right.$, $\varphi_{\mathrm{SAK}}=0.658 \pm 0.031 \mathrm{SE}$ ). The annual probability of detecting a uniquely marked piping plover across both study areas was $0.846 \pm 0.029$ SE.

There were no adult piping plovers marked or resighted in the pre-flood years and thus the results of our analyses reflect annual adult survival after the flood. 


\section{Breeding Population Size}

On the Garrison Reach, our estimate of BPOP for piping plovers was higher in the two pre-flood years than in the year immediately following the flood (table 15). However, our estimate of BPOP for piping plovers steadily increased in 2013 and 2014; the 2014 BPOP estimate was the highest estimate of BPOP for piping plovers during any of the years of the study.

On Lake Sakakawea, our piping plover BPOP estimates did not reflect similar patterns to what was seen on the Garrison Reach. The BPOP estimate was highest in 2007 (a preflood year), but BPOP estimates were equivalent during 2008 (pre-flood) and 2013 (post-food). BPOP estimates were lowest during 2014 (a post-flood year) and second-lowest in 2012 (the year immediately following the flood) (table 16).

Our estimates for least tern breeding population sizes did not reflect any annual variability among the years of the study. However, breeding population sizes per sampling unit were more variable during 2012-13 than any of the other years in the study (table 14).

\section{Mark and Recapture of Least Terns}

The daily detection probability of least tern chicks was lower in the years in which only metal and alphanumeric bands were used to uniquely mark chicks (2013-14) than in years in which terns were marked with unique combinations of color bands and metal bands (table 12).

During 2012-15 we recaptured a total of 54 least terns that were originally banded with color band only combinations during 2012 (table 17). Of these, only 8 (15 percent) would have been uniquely identifiable without recapture (that is, by sight only) in the year following their original banding. During 2012-15, we recaptured 36 least terns originally banded with alphanumeric bands in a year subsequent to their original banding. None of these individuals were missing alphanumeric bands.

We included a total of 183 uniquely marked least terns in our analysis of adult survival (table 13). The annual apparent survival of uniquely marked adult least terns was 0.868 $\pm 0.041 \mathrm{SE}$. The annual probability of detecting a uniquely marked least tern was $0.590 \pm 0.048 \mathrm{SE}$. There were no adult least terns marked or resighted in the pre-flood years and thus the results of our analyses reflect annual adult survival after the flood.

Table 13. Ranked set of Cormack-Jolly-Seber models used to estimate daily least tern chick survival to 30 days following the third stage of model selection: examination of the effect of the 2011 Missouri River flood. Models ranked according to lowest Quasi-Akaike's Information Criterion (QAICc) value corrected for small sample size and overdispersion ( $\hat{c}=1.25)$. For all models, detection $(p)$ was parameterized as $p$ (postF*year*age + age ${ }^{*}$ year* ${ }^{*} 2$ toF).

[No., the model rank; Pred., the prediction the model was intended to represent; $\varphi$, survival; $\triangle$ QAICc, the change in QAICc relative to the top-ranked model; $k$, the number of parameters in the model; $w_{i}$, the model weight; QDeviance, quasi-deviance; *, a multiplicative relationship; +, an additive relationship; $<$, less than]

\begin{tabular}{|c|c|c|c|c|c|c|}
\hline No. & Pred. & Model $(\varphi)$ & $\triangle$ QAICc & $\boldsymbol{k}$ & $w_{i}$ & QDeviance \\
\hline${ }^{1} 1$ & 3 & postF + d1 toF + year*d1toF + d1 toF*age & 0.00 & 27 & 0.94 & $2,390.83$ \\
\hline 2 & 9 & postF + d1 toF*firstyear + d1 toF*age & 6.40 & 24 & 0.04 & $2,403.38$ \\
\hline 4 & 7 & $\begin{array}{l}\text { postF }+\mathrm{d} 1 \text { toF* preflood }+\mathrm{d} 1 \text { toF*postflood }+\mathrm{d} 1 \text { toF } * \text { floodtrend }+ \\
\text { d1 toF*age }\end{array}$ & 13.23 & 25 & $<0.00$ & $2,408.17$ \\
\hline 6 & 1 & postF $+\mathrm{d} 1$ toF $+\mathrm{d} 1$ toF*age & 28.83 & 23 & $<0.00$ & $2,427.85$ \\
\hline
\end{tabular}

${ }^{1} \mathrm{QAICc}$ of top-ranked model was 6,546.67. 
Table 14. Sample of piping plover and least tern adults used to estimate annual apparent survival. Plovers and terns were captured and banded during $2012-14$, and resighted by U.S. Geological Survey crews along the Garrison Reach and Lake Sakakawea during 2012-15.

[Post-flood refers to years following the 2011 Missouri River flood. GRR, Garrison Reach; SAK, Lake Sakakawea]

\begin{tabular}{|c|c|c|c|c|c|c|}
\hline \multirow{2}{*}{ Species } & \multirow{2}{*}{ Study area } & \multicolumn{4}{|c|}{ Post-flood } & \multirow{2}{*}{ Total } \\
\hline & & 2012 & 2013 & 2014 & 2015 & \\
\hline \multirow[t]{3}{*}{ Piping plover } & GRR & 93 & 200 & 341 & 266 & 441 \\
\hline & SAK & 127 & 187 & 178 & 138 & 392 \\
\hline & Total & 216 & 375 & 498 & 410 & 810 \\
\hline Least tern & Total & 59 & 73 & 124 & 89 & 183 \\
\hline
\end{tabular}

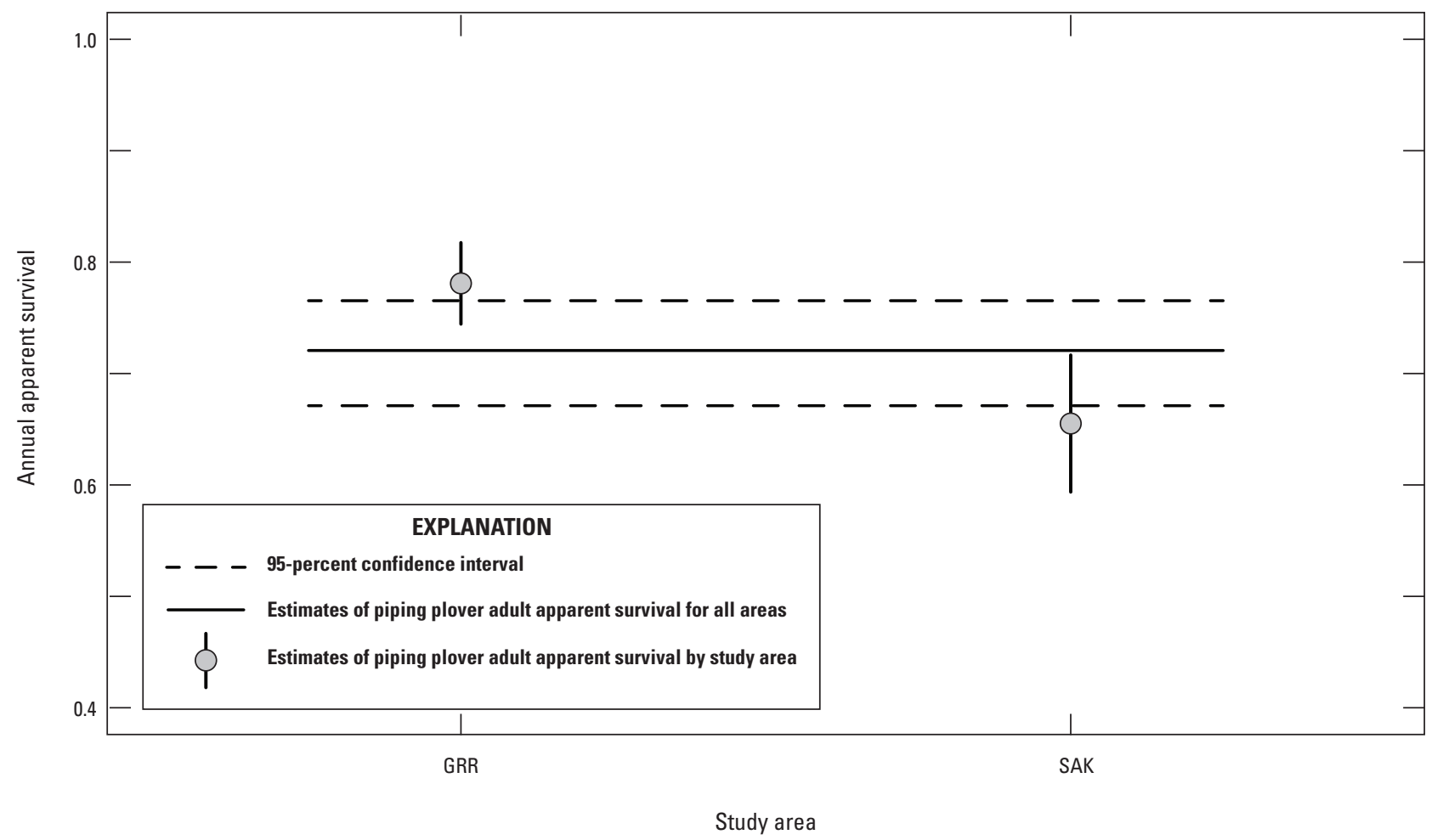

Figure 14. Estimates of piping plover adult annual apparent survival by study area and for both study areas. 
Table 15. Estimates of minimum breeding population (MINBPOP) size and breeding population size (BPOP) for piping plovers (PIPL) and least terns (LETE) nesting along the Garrison Reach before (2006-7) and after (2012-14) the 2011 Missouri River flood. Also presented are the 95-percent confidence intervals (CI) associated with the MINBPOP estimates and coefficient of variations (CV). MINBPOP values are not adjusted for imperfect detection and thus are a biased estimate of BPOP. Detection ratios (MINBPOP/BPOP) ranged from 0.71 to 0.98 for LETE in 2006-7 and from 0.51 to 0.79 for PIPL in 2006-7. We used 2012-14 estimates of nest success and extrapolated from figure 30 from Shaffer and others (2013) to determine detection ratios for PIPL and LETE in 2012-14; BPOPs calculated using these extrapolations are designated with a " ."

[MINBPOP, minimum breeding population; BPOP, breeding population size; \%, percent; CI, confidence interval; CV, coefficient of variations; , BPOPs calculated using extrapolations from Shaffer and others (2013)]

\begin{tabular}{lcccccc}
\hline \multirow{2}{*}{ Species } & \multirow{2}{*}{ Year } & \multirow{2}{*}{ MINBPOP } & \multirow{2}{*}{ BPOP } & \multicolumn{2}{c}{ 95\% CI } & \multirow{2}{*}{ CV } \\
\cline { 1 - 1 } \cline { 5 - 6 } Piping plover & 2006 & 220 & $374-432$ & 188 & 252 & 7.3 \\
& 2007 & 277 & $352-411$ & 216 & 337 & 10.8 \\
& 2012 & 175 & $\sim 180-210$ & 98 & 252 & 22.0 \\
& 2013 & 225 & $\sim 280-320$ & 140 & 392 & 37.1 \\
\multirow{3}{*}{ Least tern } & 2014 & 317 & $\sim 400-450$ & 292 & 342 & 3.9 \\
& 2006 & 189 & $231-266$ & 168 & 210 & 5.6 \\
& 2007 & 183 & $206-231$ & 159 & 206 & 6.3 \\
& 2012 & 220 & $\sim 240-260$ & 98 & 420 & 45.5 \\
& 2013 & 172 & $\sim 180-190$ & 100 & 332 & 46.5 \\
& 2014 & 181 & $\sim 200-210$ & 136 & 228 & 13.0 \\
\hline
\end{tabular}

Table 16. Estimates of minimum breeding population (MINBPOP) size and breeding population size (BPOP) for piping plovers (PIPL) nesting along Lake Sakakawea before (2007-8) and after (2012-14) the 2011 Missouri River flood. Also presented are the 95-percent confidence intervals (CI) associated with the MINBPOP estimates and coefficient of variations (CV). MINBPOP values are not adjusted for imperfect detection and thus are a biased estimate of BPOP. Detection ratios (MINBPOP BPOP) ranged from 0.50 to 0.67 for PIPL in 2007-8. We used 2012-14 estimates of nest success and extrapolated from figure 30 from Shaffer and others (2013) to determine detection ratios for PIPL in 2012-14; BPOPs calculated using these extrapolations are designated with a " ."

[MINBPOP, minimum breeding population; BPOP, breeding population size; \%, percent; CI, confidence interval; CV, coefficient of variations; $\sim$, BPOPs calculated using extrapolations from Shaffer and others (2013)]

\begin{tabular}{lcccccc}
\hline \multirow{2}{*}{ Species } & \multirow{2}{*}{ Year } & \multirow{2}{*}{ MINBPOP } & \multirow{2}{*}{ BPOP } & \multicolumn{2}{c}{ 95\% Cl } & \multirow{2}{*}{ CV } \\
\cline { 5 - 6 } \cline { 5 - 6 } Piping plover & 2007 & 658 & $1065-1311$ & 364 & 952 & 22.3 \\
& 2008 & 590 & $884-1046$ & 325 & 856 & 22.5 \\
& 2012 & 452 & $\sim 500-570$ & 125 & 779 & 36.2 \\
& 2013 & 531 & $\sim 830-1000$ & 338 & 724 & 18.2 \\
& 2014 & 228 & $\sim 370-470$ & 104 & 352 & 27.2 \\
\hline
\end{tabular}


Table 17. Number of individual least terns banded between 2012 and 2014 that were missing color bands (Color) or alphanumeric bands (Alpha) based on the number of years between recapture.

$[n$, the number of individuals that were missing bands when recaptured; $N$, the total number of individuals captured]

\begin{tabular}{crrrr}
\hline \multirow{2}{*}{ Years } & \multicolumn{2}{c}{ Color band } & \multicolumn{2}{c}{ Alpha band } \\
\cline { 2 - 5 } & $\boldsymbol{n}$ & $\boldsymbol{N}$ & $\boldsymbol{n}$ & $\boldsymbol{N}$ \\
\hline 1 & 5 & 12 & 0 & 31 \\
2 & 10 & 10 & 0 & 5 \\
3 & 31 & 32 & 0 & 0 \\
\hline
\end{tabular}

\section{Discussion}

The high river flows during the 2011 Missouri River flood contributed to vegetative scour on existing sandbars and led to the creation of new and larger sandbars along the Garrison Reach. In the years following the flood, newly exposed sand was eroded and vegetation growth occurred in some areas; however, generally there was an abundance of sandbar habitat that remained available to terns and plovers at the Garrison Reach.

Early in the 2011 nesting season, Lake Sakakawea reached maximum water level (565 m mean sea level [MSL]) for the first time since the 1997 flood and the water level remained high for the entire season. By May 15, 2012 (the typical beginning of the plover nesting season), the water level of Lake Sakakawea had dropped to $559.4 \mathrm{~m}$ MSL. On average, the water level of Lake Sakakawea increased more than $1.5 \mathrm{~m}$ during the plover nesting season (May 15 to June 30) (Anteau and others, 2012b). However, during the 2012 nesting season, the water level only increased $0.6 \mathrm{~m}$, which resulted in shorelines that were freshly scoured of vegetation and remained mostly uninundated during the nesting season (Anteau and others, 2014a). During 2013, the water level of Lake Sakakawea was $557 \mathrm{~m}$ MSL (May 15) and had increased $2.5 \mathrm{~m}$ by the end of the nesting period (June 30). During 2014, Lake Sakakawea started the nesting season at $560 \mathrm{~m}$ MSL and the water level increased $2.1 \mathrm{~m}$. The following is a comparison of water-level dynamics of Lake Sakakawea from 2006 to 2009 and 2012 to 2014: (1) 2012 stands out as the best habitat conditions (2006-14) because a large amount of new habitat was exposed and remained uninundated throughout the season (Anteau and others, 2012a, 2014b); (2) 2013 was similar to 2007 and 2008, when new habitat was exposed in early spring and then later mostly inundated throughout the nesting season; and (3) 2014 was similar to that of 2009, when no new habitat was exposed in spring and existing habitat was partially inundated during the nesting season. The following sections address the five goals previously listed in the "Objectives" section.

\section{Estimate Survival to Hatch of Least Tern and Piping Plover Nests and Compare to Pre-Flood Estimates}

The cumulative survival of piping plover nests to hatch (35 days) was best explained by models accounting for annual differences in survival probability that were not suggestive of any overall change in nest survival for all years following the flood; however, on Lake Sakakawea and the Garrison Reach, the highest cumulative nest survival estimates were in the year immediately following the flood. Our results indicate that although nest survival in 2012 may have been higher than usual, in part due to the effect of the flood, the influence of this event on nest survival for piping plovers seemed to attenuate over time.

Piping plovers preferentially select nest sites with gravel or cobble substrate and demonstrate higher nest survival on sites with sparse vegetation (Gaines and Ryan, 1988). This tendency is explained by the increased crypsis of nests on cobble or gravel substrate in combination with the decreased outward visibility associated with dense vegetation (Anteau and others, 2012a). As a result, we might expect nest success to be highest in the first year after the flood because unvegetated habitat would be most available in both study areas. On the Garrison Reach, the flood resulted in the creation of new sandbars, which would have been ideal for piping plover nesting because they would have been unvegetated and covered with uneroded nesting substrate but also because they would have added new areas for predators to search or would have facilitated more space between nests. However, Catlin and others (2011) observed no difference in plover nest success between engineered sandbars, which were similar to newly created natural sandbars, and the older and more densely vegetated natural sandbars located on the Gavins Point Reach. Without active management, sandbars can become revegetated and eroded within only a few years (Catlin, 2009). By 2013, the sandbars that would have been newly created or scoured in 2012 had already begun to erode and revegetate.

Interestingly, the daily survival rates of plover nests initiated on the Garrison Reach in pre-flood years varied with seasonal date and nest age, whereas nests initiated post-flood did not. Prior to the flood, piping plover nest survival increased as the season progressed and as the age of the nest increased, which is likely in part due to a large proportion of early nests being inundated by high spring flows on the Garrison Reach during the pre-flood period (Shaffer and others, 2013). The extremely high flood stage produced post-flood sandbars that were substantially higher in elevation than pre-flood sandbars, which may have afforded post-flood nesting birds greater security from flow-induced nest loss.

On Lake Sakakawea, the drop in reservoir levels between 2011 and 2012 resulted in scoured shorelines, which is believed to increase the ability of piping plovers to detect approaching terrestrial nest predators (Anteau and others, 2012a). Lake Sakakawea is often subjected to extreme 
mid-season water-level rises that inundate nesting habitat and often destroy plover nests during incubation. In most years during which we have worked on Lake Sakakawea, nest flooding due to reservoir water-level rise was a predictable and marked source of nest mortality (Anteau and others, 2012a); however, in 2012 there was no significant mid-season reservoir level rise. The lack of mid-season water-level rise, coupled with the low nesting densities and extensive nesting habitat available, made conditions ideal for piping plover nests to survive until hatching. Based on model estimates informed by 2006-9 nesting data, Anteau and others (2012a) predicted that when nest inundation was unlikely (such as 2012), plovers could have as much as 62-65 percent nest success (assuming 35 and 31 days exposure, respectively). Our estimate for nest survival in 2012 was generally similar to that earlier prediction and more consistent with plovers nesting elsewhere (compare to Anteau and others, 2012a). In contrast, water levels during the spring of 2009 and 2014 were higher than the previous summer, thus there was no new habitat exposed. Moreover, in those years water levels increased more than $2 \mathrm{~m}$ during the nesting period, resulting in marked decreases in nest survival (Anteau and others, 2012a). During 2007, 2008, and 2013, there were significant increases in water level during the nesting period, although these nesting periods started with newly exposed shorelines that allowed for water-level increase without inundating all of the available nesting habitat. In any case, intensity and timing of mid-summer increases in water levels is the largest known factor affecting plover nest survival on reservoirs (Anteau and others, 2012a), and our nest survival predictions were similar among groups of years that had similar water levels and water-level dynamics.

As was the case for piping plovers, daily survival of least tern nests was best explained by models accounting for annual variability in nest survival unrelated to flood effects. However, where piping plover nest survival was highest in the year immediately following the flood, least tern nest survival was higher than piping plover nest survival in all years, with the highest cumulative nest survival occurring in the preflood year 2007. On the surface, these results indicate that the nesting habitat created by the flood was no better or worse for least terns than the nesting habitat available prior to the flood. Although both species clearly benefit from the creation of sandbars for nesting, the size of the least tern population coupled with the differences in their nest site selection criteria may explain this lack of effect (Sherfy and others, 2012b; Stucker and others, 2012). Terns are colonially nesting species which means that they tend to nest in groups, and thus the same number of nesting terns does not necessarily require the same amount of "nesting" habitat as would nesting plovers; for example, low-lying natural sandbars typically support colonies of 7-8 pairs of terns (Stucker and others, 2013). Stucker and others (2013) determined that nest survival was lower on natural sandbars relative to those engineered on the Gavins Point Reach. This effect was in part attributed to the higher elevation of these sandbars and associated decreased presence of wet-sand substrate (Stucker and others, 2013).
Following the flood at the Garrison Reach, the elevation of sandbars was generally higher than pre-flood elevations on the same locations.

\section{Estimate Survival to Fledging Age of Least Tern and Piping Plover Chicks and Compare to Pre-Flood Estimates}

For the Garrison Reach and Lake Sakakawea study areas, cumulative survival to fledging (25 days) for piping plovers exhibited significant annual variability. This variability was best explained by models that, along with supporting a difference between pre-flood and post-flood years, represented scenarios in which the probability of survival following the flood followed a log-linear trend. Chick survival on Lake Sakakawea and the Garrison Reach responded in different directions. On the Garrison Reach, post-flood piping plover chick survival was lowest in 2012 and increased by year until 2014; whereas on Lake Sakakawea, the highest survival estimates for piping plover chicks occurred immediately after the flood, in 2012. In this region, sources of piping plover chick mortality typically include predation, weather events, and water-level rise.

On Lake Sakakawea, rises in water levels that occur during the summer inundate potential brooding habitat for plover chicks (Anteau and others, 2014b,c). Although in most cases summer water-level rises simply reduce the amount of suitable brooding habitat, in some cases summer rises can completely inundate islands with plover broods prior to their fledging. Considering water-level dynamics during each year, it is not surprising that chick survival was near lowest during 2008 because the water level of Lake Sakakawea during that year increased $3.4 \mathrm{~m}$ during the nesting period (May 15 to June 30) and increased another $2.0 \mathrm{~m}$ during July (U.S. Army Corps of Engineers, 2017), when many chicks are present. However, it seems that water-level dynamics are less likely implicated in the low chick survival observed during 2013 because, although water level increased $2.4 \mathrm{~m}$ during the nesting season, it only increased $0.1 \mathrm{~m}$ during July (U.S. Army Corps of Engineers, 2017). The greatest chick survival estimate at Lake Sakakawea was during 2012, when water level only increased slightly during the nesting season $(0.6 \mathrm{~m})$ and actually decreased $0.1 \mathrm{~m}$ during July (U.S. Army Corps of Engineers, 2017). These years provide some circumstantial evidence for the importance of water-level dynamics during the breeding season on chick survival; however, there seem to be other important but unexplained factors affecting chick survival, as exemplified during 2013.

In contrast to the Garrison Reach, the shorelines of Lake Sakakawea have large amounts of cobble substrate and other structures (for example, dead trees, rocks, sticks, and so forth) that can serve as cover for piping plover chicks (Anteau and others, 2014b). Additionally, whether due to a low density of ground-nesting species or predators themselves, shorelines along Lake Sakakawea do not seem to experience the same 
degree of predator pressure during nesting as on the Garrison Reach (Anteau and others, 2012a); however, chick survival estimates at Lake Sakakawea are generally lower than those on the Garrison Reach. We previously determined that island habitat on Lake Sakakawea had much lower fledging rates, possibly because of greater use of those areas by gulls and to some extent higher plover brood densities (Anteau and others, 2014c). Anteau and others (2014c) reported only weak evidence to support density dependence in survival of chicks to fledging age. It is plausible that summer increases in water levels are a component of mechanisms that drive density dependence through the decrease in available habitat. During 2012 there was a vast amount of brooding habitat available throughout the summer. As predicted by Anteau and others (2014c), density-dependent processes would likely not be a strong factor affecting chick survival at Lake Sakakawea during 2012; however, we suspect that water-level dynamics during the nesting and brooding periods likely interact with the vulnerability of plovers to predation because they affected density of broods and how they utilized the habitat (Murphy and others, 2003; Cohen and others, 2009; Anteau and others, 2014b,c; Wiltermuth and others, 2015). Further analysis and work is needed to better understand vulnerability of plover chicks to predation under the changing habitat conditions observed at Lake Sakakawea.

On the Garrison Reach, 2012 was the post-flood year with the highest piping plover nest survival and the lowest chick survival. We did not notice any major differences on the Garrison Reach between 2012 and 2013-14 that could help explain this lower chick survival; however, the overall population size of breeding piping plovers was lower in 2012 than any other year, and this was reflected in lower nesting densities during this year than in other years. Although high nesting densities may negatively affect piping plover chick survival and growth (Anteau and others, 2014c; Catlin and others, 2014), there is little evidence to support density dependent processes, including inter-brood aggression, at the densities observed in most breeding areas (Anteau and others, 2014c). Although predation of chicks could be a mechanism of density dependence, predation rates could be independent of chick density due to dynamics in predator communities and abundance that are driven by many external factors (Sargeant and others, 1993); however, the Garrison Reach generally has much less substrate available for hiding broods in comparison to habitat at Lake Sakakawea. This would have been particularly true during 2012, when sandbars would have been newly created (and thus lacking vegetation) or newly scoured. It is possible that the lower nesting densities during 2012, coupled with little hiding substrate, made piping plovers more easily seen by predators. This speculation indicates that habitat features that help chicks hide from predation could have been a limiting factor that year.

The cumulative survival of least terns to fledging (18 days) on the Garrison Reach was best explained by a model that contained annual differences in survival but not necessarily in reference to whether or not those years occurred pre- or post-flood. Least tern chick survival was highest during 2012, the year immediately following the flood. We observed no substantial differences in habitat abundance or structure between 2012 and the other post-flood years other than the generally low amount of vegetation that could have been used for cover during 2012.

Although one can make some indirect inferences on annual foraging conditions for piping plovers and consequences for survival based on weather and water-level dynamics (for example, Anteau, 2012a; Brudney and others, 2013; Anteau and others, 2014c), the same is more difficult for least terns. Least terns are piscivorous, semi-precocial, and dependent on the foraging success of their parents until they fledge (Sherfy and others, 2012a). Additionally, predictions of forage abundance for terns based on environmental characteristics are likely more tenuous than for plovers because fish generally live longer and occupy higher trophic levels than the invertebrate foods of plovers. Chick growth and survival are both affected by the availability of appropriately sized fish to feed least tern young (Atwood and Kelly, 1984; Massey and others, 1992; Dugger, 1997). Although Stucker and others (2012) found no difference in fish forage base between natural and constructed sandbars, they did note that there were significant interannual differences in fish species abundance along the Gavins Point Reach and that greater fish abundances occurred at shallower depths. Thus, it is possible the among-year differences in least tern chick survival could reflect differences in the availability of their fish forage base, perhaps in relation to the abundance of shallow-water habitat. Because shallowwater habitats are associated with sandbar complexes, it is possible that one effect of the 2011 flood was the creation of additional shallow-water habitats, which could have led to an increase in the number of least tern foraging areas, foraging success, or prey fish habitat abundance, any combination of which could have led to higher chick provisioning rates and ultimately survival.

\section{Estimate Annual Adult Survival of Piping Plovers and Compare to Pre-Flood Estimates}

There were no estimates of annual adult survival available for the pre-flood period for piping plovers breeding on Lake Sakakawea or the Garrison Reach. Instead, we can compare our apparent survival estimates to those published for plovers breeding in similar habitat types under conditions similar to those that would have existed on both study areas prior to the flood.

True survival of piping plovers nesting along riverine shoreline and sandbar habitat on Gavins Point Reach, Nebraska, and Lewis and Clark Lake, South Dakota, during 2005-11 was estimated to be 0.76 ( \pm 0.049 SE) (Catlin and others, 2015). Catlin and others (2015) reported adult survival estimates declined between 2005 and 2011 and seemed to be lowest in 2010 (that is, the year prior to the flood). The conditions experienced by piping plovers nesting on the Garrison 
Reach in pre-flood years are probably most similar to those experienced in this region. Our annual apparent survival estimate for piping plovers nesting on the Garrison Reach during 2012-14 was 0.75 (95-percent confidence interval: 0.72-0.79). Because apparent survival rates are a composite of survival and fidelity, our estimates indicate that the survival of adults breeding on the Garrison Reach is equivalent to that on the Gavins Point Reach (if fidelity is near 100 percent) or slightly higher.

Of available estimates, the annual apparent survival of piping plovers nesting along reservoir shoreline habitat of Lake Diefenbaker, Saskatchewan, Canada, during 2002-8 likely reflects conditions most similar to those experienced by piping plovers breeding on Lake Sakakawea. Both lakes are large reservoir impoundments that experience intra- and interannual water-level changes and are located within dispersal distance of wetlands used for nesting by piping plovers. During 2002-8, piping plovers nesting on Lake Diefenbaker experienced apparent annual survival rates of 0.76 (95-percent confidence interval: 0.72-0.82) (Roche and others, 2010). During 2012-14, plovers nesting on Lake Sakakawea experienced annual apparent survival rates of 0.65 (95-percent confidence interval: 0.59-0.72), indicating a significantly lower apparent survival rate than on Lake Diefenbaker.

Based on available data, it is unclear whether the apparent survival estimates for plovers on Lake Sakakawea are comparatively lower than those of Lake Diefenbaker due to differences in permanent emigration rates or true survival. Lake Sakakawea is positioned within close proximity to several other breeding habitats: a river reach, Lake Oahe, and hundreds of wetlands that are used by piping plovers, and there is evidence of dispersal among these areas both within and among years (Murphy and others, 2003; McCauley and others, 2015; Roche and others, 2016). If piping plovers nesting on Lake Sakakawea had a higher tendency to disperse than plovers nesting on the Garrison Reach, then a corresponding effect on post-flood apparent survival could occur. For example, if plovers emigrated out of Lake Sakakawea and the Garrison Reach and remained in the regions they emigrated to during 2012-14, this emigration would be captured in our estimate of apparent survival; however, like Lake Sakakawea, Lake Diefenbaker is located near nesting habitat to which plovers could permanently disperse. Accordingly, our continued research efforts will be better suited to address these questions of survival compared to emigration.

\section{Estimate Annual Breeding Population of Least Terns and Piping Plovers and Compare to Pre-Flood Estimates}

The Garrison Reach and Lake Sakakawea study areas exhibited lower piping plover breeding population sizes in the year immediately following the flood (2012). On the Garrison Reach, the population size increased such that by 2014, levels were higher than in the years prior to the flood; however, on
Lake Sakakawea, our estimate of breeding population size was only at pre-flood levels during 2013, with 2014 breeding population sizes significantly lower and equivalent to sizes in 2012. Possible explanations for the smaller breeding population sizes in the year immediately following the flood include a combination of the emigration of breeding adults to other northern Great Plains nesting locations, low reproductive success during 2010-11, and increased adult mortality during 2010-12.

During 2011, the amount of water in the Missouri River system left none of the traditional nesting habitat for piping plovers available for use on the Garrison Reach or Lake Sakakawea. Presumably in response to loss of their traditional nesting areas, plovers were observed using non-traditional nesting habitats such as parking lots. Mark-recapture work in the Canadian prairies has revealed that when flooding occurred on reservoirs like Lake Diefenbaker, plovers moved to nest in nearby non-flooded locations in the Prairie Coteau (Roche and others, 2012). Lake Sakakawea and the Garrison Reach are on the western boundary of the North Dakota alkali lakes region, which is an area also used for nesting by piping plovers; therefore, plovers that traditionally nested on flooded sections of the Garrison Reach and Lake Sakakawea potentially had other nearby options available for nesting in 2011. During 2011, counts of adult piping plovers in the alkali lakes region during the June census were lower than in the previous year but higher than they would be during the next 3 years (Brennan and others, 2014). Unfortunately, there was no markrecapture work done during this time so it is unknown whether the increased population sizes in the alkali lakes were due to piping plovers emigrating out of the Garrison Reach and Lake Sakakawea study areas. If plovers did emigrate into these other areas during 2011 and experienced reproductive success, it is possible they would have continued to nest in these areas even when nesting habitat again became available on the Missouri River due to the association between reproductive success and site fidelity (Roche and others, 2012; Catlin and others, 2015). There would then be a lag time between the emergence of nesting habitat on the Missouri river and use of this habitat by nesting piping plovers.

Because there was little nesting habitat available on the reservoir or river during the flood, the number of chicks that fledged from these two study areas was probably negligible. Moreover, in the 3 years leading up to the flood event, water levels on Lake Sakakawea were not conducive to fledging of plover chicks (Anteau and others, 2012a, 2014c; Wiltermuth and others, 2015). During all 3 years leading up to the flood event, water levels increased more than $2.3 \mathrm{~m}$ during the nesting period and more than $1.1 \mathrm{~m}$ during the brood rearing period (U.S. Army Corps of Engineers, 2017). Piping plovers do not necessarily return to nest in the same locations they hatch from, but based on preliminary analysis of dispersal data for this study and published estimates for elsewhere in the Missouri River system, there is some degree of site fidelity at least to a "study area" (Catlin and others, 2015). For example, of the 95 plovers resighted during 2015 that had hatched on the Garrison Reach in 2014, 70 of them were observed on the 
Garrison Reach. Similarly, of the 15 plovers observed during 2015 that had hatched on Lake Sakakawea in 2014, 13 of them were observed on Lake Sakakawea. Given the tendency of plovers to return to nest in the study area they hatched from, it seems reasonable to conclude that breeding population sizes would have, in part, been lower during 2012 because there would be no 2011 cohort to recruit into the breeding population; however, this explanation alone does not account for the difference in breeding population sizes.

Another hypothesis for the lower numbers of adult breeding plovers present at the Garrison Reach and Lake Sakakawea during 2012 is that they suffered increased mortality between our study intervals. Plovers winter on beaches of the Gulf of Mexico (Elliott-Smith and Haig, 2004). The Deepwater Horizon oil spill occurred in the Gulf of Mexico during spring and summer 2010, which could have had direct (for example, oiling) or indirect effects (for example, reduced forage, increased disturbance) on mortality during winter of 2010/2011 and the following spring migration (Henkel and others, 2012). During spring 2011, in addition to the Missouri River being flooded, much of the wetland habitats used by plovers were also flooded (K. Brennan, U.S. Fish and Wildlife Service, oral commun.). Although this obviously reduced breeding habitat for adults, it likely also forced plovers to forage in novel habitats. The oil spill on the wintering grounds and flooding conditions at nearly all of the nesting areas during the following spring in the northern Great Plains may have had synergistic effects that increased adult mortality during late 2010 through 2011.

There is also some evidence to indicate that displacement from a territory or traditional nesting location can result in lowered survival rates. This phenomenon has been observed in a number of bird species and is generally attributed to an organism's lack of knowledge about its new environment, which in turn leads to a greater risk of predation and lowered foraging success (Brown and others, 2008). There is some evidence to indicate that the same phenomenon may affect piping plovers following nest habitat flooding (Cohen and GrattoTrevor, 2011; Roche and others, 2012). By mid-summer 2007, all traditional nesting habitat used by piping plovers on Big Quill Lake in Saskatchewan was completely covered by water and piping plovers were observed nesting in non-traditional habitat such as upland areas including pastures (Gratto-Trevor, pers. obs.). Survival analyses during this period revealed that adult piping plovers that had nested at Big Quill Lake before and (or) during the flood years had lower apparent survival following the year of the flood (Roche and others, 2012). These lowered apparent survival rates did not seem to be explainable by increased permanent emigration during this period because survival rates remained lower in postflood years even when accounting for changes in emigration probability (Cohen and Gratto-Trevor, 2011); however, like the reduced recruitment between 2011 and 2012, it is highly unlikely that increased adult mortality alone could explain population size changes.

In complete contrast with piping plovers, our pre- and post-flood estimates of least tern breeding population sizes indicate there was no detectable change following the flood. There are several key demographic differences between plovers and terns that may account for why one species exhibited a response where the other did not. Least terns have higher survival rates and generally live longer than plovers (Massey and others, 1992; Renken and Smith, 1995a). In contrast to a previously published study on least tern adult site fidelity (Renken and Smith, 1995b), mark-recapture data collected on the Garrison Reach and Lake Sakakawea during 2012-15 indicated that breeding adult least terns displayed high fidelity to their study area. For example, out of 101 uniquely marked least terns observed nesting in 2015, only 8 were observed nesting in a different study area than they had nested in 2014.

Unlike piping plovers, there is not much information available on dispersal tendencies in least terns. It is unclear whether the terns that normally would have nested in 2011 simply remained on the river foraging and skipped nesting or whether they continued northward to find habitat on the Yellowstone River or other tributaries. Unlike piping plovers, which would have had to disperse tens of kilometers to find new nesting habitat during the flood year, least terns would have had to disperse much farther distances. The detection of long-distance dispersal is difficult because it requires concurrent work over a large area (Koenig and others, 1996); however, incidental sightings of banded least terns over the years have indicated that they are capable of very large interannual movements as adults. For example, Renken and Smith (1995b) report that at least four least terns banded as adults were observed during subsequent breeding seasons in Indiana and South Dakota, more than $300 \mathrm{~km}$ from their original nesting locations.

Another major difference between the two species is in the area of natal fidelity and recruitment into the breeding population. Although piping plovers have a tendency to return to the same general region in which they hatched the year previously (Saunders and others, 2014; Catlin and others, 2015), least terns show no such tendency (Renken and Smith, 1995b). Importantly, least terns do not seem to recruit into breeding populations the year after they hatch like piping plovers do (Massey and Atwood, 1981), which means that even if the 2011 flood caused a decrease in recruitment to the Garrison Reach, it would not have been detected until 2013. Our estimates of least tern breeding population size were slightly lower in 2013 than 2012 but did not exhibit the same magnitude of difference as the change in piping plover breeding population size during the same period.

There is limited information about least tern natal dispersal in part because most of them simply do not return to the region in which they hatched (Renken and Smith, 1995b). Least terns banded on the Garrison Reach during 2012-15 
have been recaptured/resighted nesting in regions hundreds or thousands of kilometers from their hatch location (for example, Nebraska, Japan) and Boyd and Thompson (1985) reported capturing a nesting adult in Kansas that had been originally banded as a juvenile in Texas (more than 1,200 km). Such observations indicate least terns are capable of recruiting into very different breeding populations than those from which they hatched. Given this tendency, it is unlikely that most of the least terns currently nesting on the Garrison Reach of the Missouri River actually hatched on this same stretch of river. The lack of change in the breeding population size following the flood is consistent with this assumption; recruitment would not necessarily have been different during 2012 because most of the terns recruiting into the population were not produced along the Garrison Reach.

\section{Evaluate Feasibility of Mark-Resight Techniques to Estimate Site Fidelity and Annual Survival of Adult Least Terns}

During 2012-14 we were able to successfully estimate chick survival to fledging and annual apparent survival for least terns. We determined that overall detection probability of least tern chicks was highest when combinations of color bands and stainless steel metal bands were used. This banding scheme resulted in higher daily detection probability of least tern chicks before and after fledging. A downside of using color bands on chicks is that due to the size of least tern chick legs, the number of combinations available for use is limited without placing bands above the tibiotarsal joints if chicks are banded at less than 8 days. After this point, the chicks can be recaptured and the color bands placed below the joint, but this requires an extra level of effort on the part of researchers and increased handling of the chicks.

We determined that banding with color bands and metal bands was not ideal for estimating annual survival of least terns after they had fledged. Least terns exhibit greater band loss than we see when marking piping plovers. This is true for metal bands, which are often slipped off the foot while terns are still chicks, and for color bands; we also noted band loss of heat-sealed color bands on adult terns. Additionally, because least terns do not return to nest until 2 years after hatching, any tern marked as a chick would have an even longer time period to lose color bands than is typically the case for piping plovers, ultimately making them unidentifiable without recapture. Beginning in 2013, we started banding all terns with yellow darvic alphanumeric leg bands on the lower leg opposite of the leg carrying the stainless steel metal band. Although these bands proved more difficult to resight on least tern chicks, they exhibited much higher band retention than typical color bands and in several cases remained on terns that had lost their stainless steel metal band.

\section{References Cited}

Anteau, M.J., 2012, Do interactions of land use and climate affect productivity of waterbirds and prairie-pothole wetlands?: Wetlands v. 32, p. 1-9.

Anteau, M.J., Shaffer, T.L., Sherfy, M.H., Sovada, M.A., Stucker, J.H., and Wiltermuth, M.T., 2012a, Nest survival of piping plovers at a dynamic reservoir indicates an ecological trap for a threatened population: Oecologia, v. 170, p. 1167-1179.

Anteau, M.J., Shaffer, T.L., Wiltermuth, M.T., and Sherfy, M.H., 2014a, Landscape selection by piping plovers has implications for measuring habitat and population size: Landscape Ecology, v. 29, p. 1033-1044.

Anteau, M.J., Sherfy, M.H., and Wiltermuth, M.T., 2012b, Selection indicates preference in diverse habitats-A ground-nesting bird (Charadrius melodus) using reservoir shoreline: PLoS ONE, v. 7, n. e30347.

Anteau, M.J., Wiltermuth, M.T., Sherfy, M.H., and Shaffer, T.L., 2014b, Measuring and predicting abundance and dynamics of habitat for piping plovers on a large reservoir: Ecological Modeling, v. 272, p. 16-27.

Anteau, M.J., Wiltermuth, M.T., Sherfy, M.H., Shaffer, T.L., and Pearse, A.T., 2014c, The role of landscape features and density dependence in growth and fledging rates of piping plovers in North Dakota, USA: Condor, v. 116, p. 195-204.

Armstrong, D.P., Raeburn, E.H., Powlesland, R.G., Howard, M., Christensen, B., and Ewen, J.G., 2002, Obtaining meaningful comparisons of nest success - Data from New Zealand robin (Petroica australis) populations: New Zealand Journal of Ecology, v. 26, p. 1-13.

Atwood, J.L., and Kelly, P.R., 1984, Fish dropped on breeding colonies as indicators of least tern food habits: Wilson Bulletin, v. 96, p. 34-47.

Boyd, R.L., and Thompson, B.C., 1985, Evidence for reproductive mixing of least tern populations: Journal of Field Ornithology, v. 56, p. 405-406.

Brennan, K., 2014, Conservation of piping plovers in the U.S. Alkali Lakes Core Area, 2014 Field Season: Summary Report, Permit \# TE207947-2, 21 p.

Brown, C.R., Brown, M.B., and Brazeal, K.R., 2008, Familiarity with breeding habitat improves daily survival in colonial cliff swallows: Animal Behaviour, v. 76, p. 1201-1210. 
Brudney, L.J., Arnold, T.W., Saunders, S.P., and Cuthbert, F.J., 2013, Survival of piping plover (Charadrius melodus) chicks in the Great Lakes Region: Auk, v. 130, p. 150-160.

Catlin, D.H., 2009, Population dynamics of piping plovers (Charadrius melodus) on the Missouri River: Blacksburg, Virginia, Ph.D. Dissertation, Virginia Polytechnic Institute and State University.

Catlin, D.H., Fraser, J.D., Felio, J.H., and Cohen, J.B., 2011, Piping plover habitat selection and nest success on natural, managed, and engineered sandbars: Journal of Wildlife Management, v. 75, p. 305-310.

Catlin, D.H., Fraser, J.D., and Felio, J.H., 2015, Demographic responses of piping plovers to habitat creation on the Missouri river: Wildlife Monographs, v. 192, p. 42.

Catlin, D., Jacobson, R., Sherfy, M., Anteau, M., Felio, J., Fraser, J., Lott, C., Shaffer, T., and Stucker J., 2010, Discussion of "Natural hydrograph of the Missouri River near Sioux City and the Least Tern and Piping Plover" by Donald G. Jorgensen: Journal of Hydrologic Engineering, v. 15, p. $1076-1078$.

Catlin, D.H., Milenkaya, O., Hunt, K.L., Friedrich, M.J., and Fraser, J.D., 2014, Can river management improve the piping plover's long-term survival on the Missouri River?: Biological Conservation, v. 180, p. 196-205.

Cochran, W.G., 1977, Sampling techniques (3d ed.): New York, John Wiley \& Sons, 428 p.

Cohen, J.B., and Gratto-Trevor, C., 2011, Survival, site fidelity, and the population dynamics of piping plovers in Saskatchewan: Journal of Field Ornithology, v. 82, p. 379-394.

Cohen, J.B., Houghton, L.M., and Fraser, J.D., 2009, Piping plover nesting density and reproductive success in response to storm and human-created changes: Wildlife Monographs, v. 173 , p. 24.

Dirks, B.J., 1990, Distribution and productivity of least terns and piping plovers along the Missouri and Cheyenne Rivers in South Dakota: Brookings, South Dakota, South Dakota State University, M.S. thesis, 65 p., accessed February 12, 2017, at http://openprairie.sdstate.edu/etd/331/.

Dixon, M.D., Boever, C.J., Danzeisen, V.L., Merkord, C.L., Munes, E.C., Scott, M.L., Johnson, W.C., and Cowman, T.C., 2015, Effects of a 'natural' flood event on the riparian ecosystem of a regulated large-river system: the 2011 flood on the Missouri River, USA: Ecohydrology, v. 8, p. 812-824.

Dugger, K.M., 1997, Foraging ecology and reproductive success of least terns nesting on the Lower Mississippi River: Columbia, Missouri, University of Missouri, Ph.D. dissertation, p. 137.
Elliott-Smith, E., and Haig, S.M., 2004, Piping plover (Charadrius melodus), in Rodewald, P.G., ed., The Birds of North America: Ithaca, N.Y., Cornell Lab of Ornithology. [Also available at https://doi.org/10.2173/bna.2.]

Gaines, E.P., and Ryan, M.R., 1988, Piping plover habitat use and reproductive success in North Dakota: The Journal of Wildlife Management, v. 52, p. 266-273.

Grant, T.A., Shaffer, T.L., Madden, E.M., and Pietz, P.J., 2005, Time-specific variation in passerine nest survival-New insights into old questions: Auk, v. 122, p. 661-672.

Henkel, J.R., Sigel, B.J., and Tylor, C.M., 2012, Large-scale impacts of the Deepwater Horizon oil spill — Can local disturbance affect distant ecosystems through migratory shorebirds?: BioScience, v. 62, p. 676-685.

Jackson, C.J., 2011, Multi-state models for panel dataThe msm package for R: Journal of Statistical Software, v. 38, p. 29, accessed February 12, 2017, at http://www.jstatsoft.org/v38/i08/.

Koenig, W.D., van Vuren, D., and Hooge, P.N., 1996, Detectability, philopatry, and the distribution of dispersal distances in vertebrates: Trends in Ecology and Evolution, v. 11, p. 514-517.

Laake, J.L., 2013, RMark-An R interface for analysis of capture-recapture data with MARK: Seattle, Wa., Alaska Fisheries Science Center, National Oceanic and Atmospheric Administration, National Marine Fisheries Service, AFSC Processed Rep 2013-01, 25 p.

Lebreton, J.D., Burnham, K.P., Clobert, J., and Anderson, D.R., 1992, Modeling survival and testing biological hypotheses using marked animals - A unified approach with case studies: Ecological Monographs, v. 62, p. 67-118.

Mabee, T.J., 1997, Using eggshell evidence to determine nest fate of shorebirds: The Wilson Bulletin, v. 109, p. 307-313.

Mabee, T.J., Wildman, A.M., and Johnson, C.B., 2006, Using egg flotation and eggshell evidence to determine age and fate of Arctic shorebird nests: Journal of Field Ornithology, v. 77, p. 163-172.

Massey, B.W., and Atwood, J.L., 1981, Second-wave nesting of the California least tern-Age composition and reproductive success: Auk, v. 98, p. 596-605.

Massey, B.W., Bradley, D.W., and Atwood, J.L., 1992, Demography of a California least tern colony including effects of the 1982-1983 El Niño: Condor, v. 94, p. $976-983$.

McCauley, L.A., Anteau, M.J., and Post van der Burg, M., 2015, Consolidation drainage and climate change may reduce Piping Plover habitat in the Great Plains: Journal of Fish and Wildlife Management, v. 7, p. 4-12. 
Murphy, R.K., Greenwood, R.J., Ivan, J.S., and Smith, K.A., 2003, Predator exclusion methods for managing endangered shorebirds - Are two barriers better than one?: Waterbirds, v. 26, 156-159.

Page, G.W., Stenzel, L.E., and Ribic, C.A., 1985, Nest site selection and clutch predation in the Snowy Plover: Auk, v. 102 , p. $347-353$.

R Core Team, 2014, R-A language and environment for statistical computing: Vienna, Austria, R Foundation for Statistical Computing, accessed February 12, 2017, at http://www.R-project.org/.

Renken, R.B., and Smith, J.W., 1995a, Annual adult survival of interior least terns (Superviviencia Anual de Sterna antillarum en Mississippi): Journal of Field Ornithology, v. 66, p. 112-116.

Renken, R.B., and Smith, J.W., 1995b, Interior least tern site fidelity and dispersal: Colonial Waterbirds, v. 18, p. 193-198.

Roche, E.A., Cohen, J.B., Catlin, D.H., Amirault-Langlais, D.L., Cuthbert, F.J., Gratto-Trevor, C.L., Felio, J., and Fraser, J.D., 2010, Range-wide piping plover survival - Correlated patterns and temporal declines: Journal of Wildlife Management, v. 74, p. 1784-1791.

Roche, E.A., Gratto-Trevor, C.L., Goossen, J.P., and White, C.L., 2012, Flooding affects dispersal decisions in piping plovers (Charadrius melodus) in Prairie Canada: Auk, v. 129 , p. 296-306.

Roche, E.A., Shafter, T.L., Dovichin, C.M., Sherfy, M.H., Anteau, M.J., and Wiltermuth, M.T., 2016, Synchrony of piping plover breeding populations in the U.S. Northern Great Plains: Condor, v. 118, p. 558-570.

Sargeant, A.B., Greenwood, R.J., Sovada, M.A., and Shaffer, T.L., 1993, Distribution and abundance of predators that affect duck production-Prairie pothole region: Northern Prairie Wildlife Research Center, U.S. Fish and Wildlife Service, Resource Publication, v. 194, p. 96.

Saunders, S.P., Arnold, T.W., Roche, E.A., and Cuthbert, F.J., 2014, Age-specific survival and recruitment of piping plovers Charadrius melodus in the Great Lakes region: Journal of Avian Biology, v. 45, p. 437-449.

Shaffer, T.L., 2004, A unified approach to analyzing nest success: Auk, v. 121, p. 526-540.

Shaffer, T.L., Sherfy, M.H., Anteau, M.J., Stucker, J.H., Sovada, M.A., Roche, E.A., Wiltermuth, M.T., Buhl, T.K., and Dovichin, C.M., 2013, Accuracy of the Missouri River Least Tern and Piping Plover Monitoring Program - Considerations for the future: U.S. Geological Survey Open-File Report 2013-1176, 74 p., with 4 appendixes, accessed February 12, 2017, at http://dx.doi.org/10.3133/ofr20131176.
Sherfy, M.H., Anteau, M.J., Swift, R.J., Shaffer, T.L., and Toy, D.L., 2018, Least tern and piping plover responses to the 2011 Missouri River flood-Nest, chick and adult datasets: U.S. Geological Survey data release, https://doi.org/10.5066/P9VHGRDD.

Sherfy, M.H., Anteau, M.J., Shaffer, T.L., Sovada, M.A., and Stucker, J.H., 2012a, Foraging ecology of least terns and piping plovers nesting on Central Platte River sandpits and sandbars: U.S. Geological Survey Open-File Report 2012-1059, 50 p., accessed February 12, 2017, at http://pubs.usgs.gov/of/2012/1059/.

Sherfy, M.H., Stucker, J.H., and Anteau, M.J., 2008, Missouri River emergent sandbar habitat monitoring plan-A conceptual framework for adaptive management: U.S. Geological Survey Open-File Report 2008-1223, 51 p., accessed February 12, 2017, at http://pubs.usgs.gov/of/2008/1223/.

Sherfy, M.H., Stucker, J.H., and Buhl, D.A., 2012b, Selection of nest-site habitat by interior least terns in relation to sandbar construction: Journal of Wildlife Management, v. 76, p. 363-371.

Stucker, J.H., Buhl, D.A., and Sherfy, M.H., 2012, Emergent sandbar construction for least terns on the Missouri RiverEffects on forage fishes in shallow-water habitats: River Research and Application, v. 28, p. 1254-1265.

Stucker, J.H., Buhl, D.A., and Sherfy, M.H., 2013, Consequences of least tern (Sternula antillarum) microhabitat nest-site selection on natural and mechanically constructed sandbars in the Missouri River: Auk, v. 130, p. 753-763.

Toy, D.L., Roche, E.A., and Dovichin, C.M., 2017, Small high-definition video cameras as a tool to resight uniquely marked interior least terns (Sternula antillarium athalassos): Waterbirds, v. 40, p. 180-186.

U.S. Army Corps of Engineers, 2017, U.S. Army Corps of Engineers, Monthly reservoir summary (0168's): U.S. Army Corps of Engineers, Omaha District, accessed February 12, 2017, at http://www.nwd-mr.usace.army.mil/rcc/programs/ bullext.html.

White, G.C., and Burnham, K.P., 1999, Program MARKSurvival estimation from populations of marked animals: Bird Study, v. 46, supplement, p. 120-139.

Wiltermuth, M.T., Anteau, M.J., Sherfy, M.H., and Pearse, A.T., 2015, Habitat selection and movements of piping plover broods suggest a tradeoff between breeding stages: Journal of Ornithology, v. 156, p. 999-1013. 
For more information about this publication, contact:

Director, USGS Northern Prairie Wildlife Research Center

8711 37th Street Southeast

Jamestown, ND 58401

701-253-5500

For additional information, visit: https://www.usgs.gov/centers/npwrc

Publishing support provided by the

Rolla Publishing Service Center 



\section{$s^{-6}$}

$\frac{2}{2}$

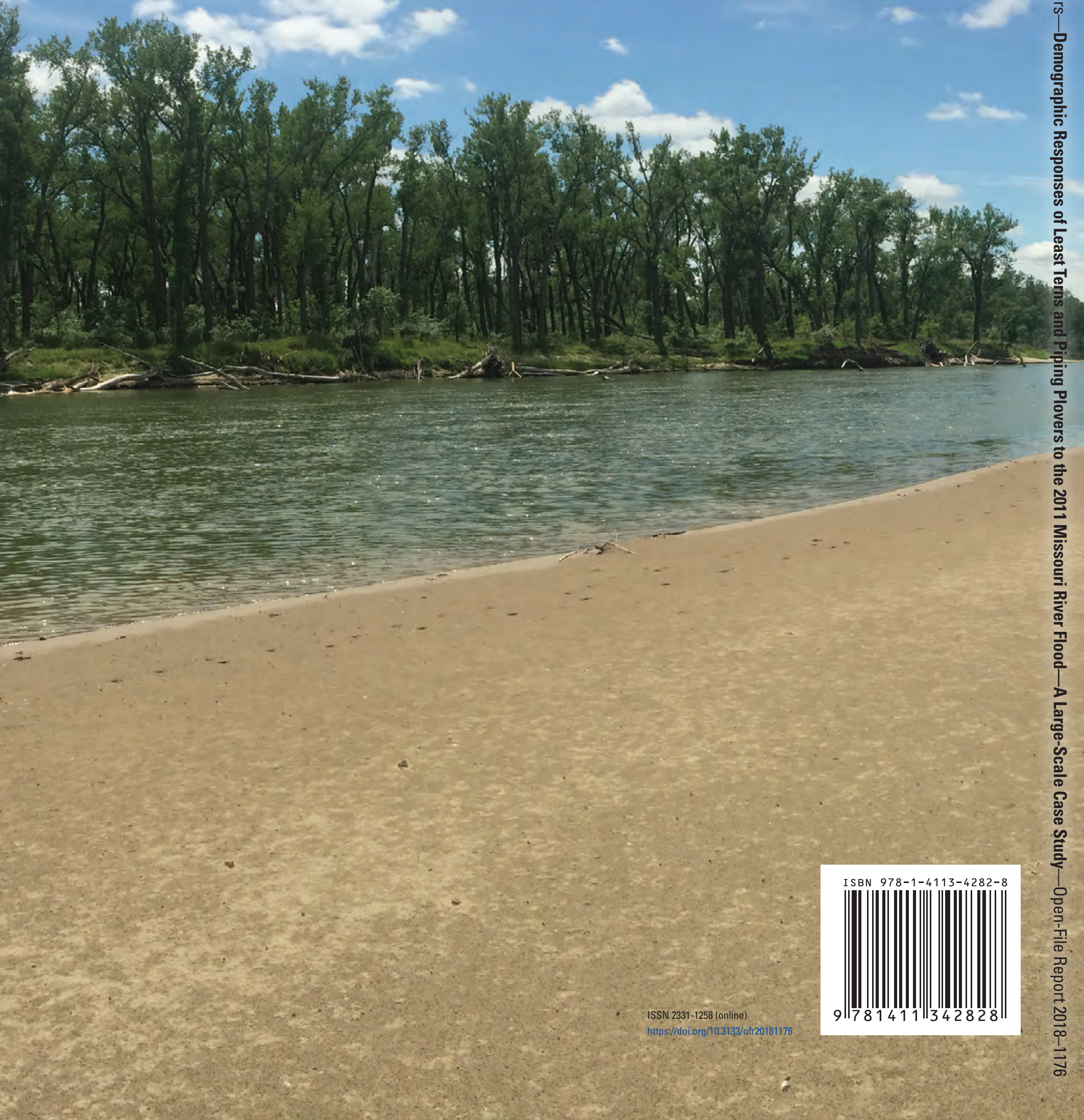

